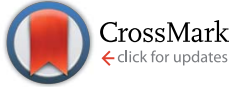

Cite this: RSC Adv., 2015, 5, 58292

Received 22nd April 2015

Accepted 26th June 2015

DOI: $10.1039 / \mathrm{c} 5 \mathrm{ra07316b}$

www.rsc.org/advances

\title{
Electrophilic trifluoromethylthiolation of thiols with trifluoromethanesulfenamide $\uparrow$
}

\author{
Marjan Jereb* and Darko Dolenc
}

The highly selective and effective, metal-free, acid promoted trifluoromethylthiolation of thiols to the corresponding trifluoromethyl disulfides is described. The aryl-, benzyl-, aliphatic-, and heteroaromatic thiols reacted selectively, thus proving excellent reaction generality. The method offers practical and easy access to the previously mostly unknown or rarely reported trifluoromethyl disulfides. Comparison of the relative reactivity of thiophenols suggests formation of an electron-deficient intermediate in the transition state, which was supported by quantum chemical calculations. The supposed reaction course is discussed.

\section{Introduction}

Fluorinated organic molecules have been gaining significance in different fields i.e. medicinal and agrochemistry, highperformance advanced materials and new reaction media such as fluorinated ionic liquids and perfluorinated solvents. ${ }^{1}$ The fluorine atom in an organic molecule brings about several stereoelectronic changes, and the $\mathrm{C}-\mathrm{F}$ bond is an important conformational and bioisosteric tool in bioorganic chemistry. ${ }^{2}$ The fluorine atom is important in inter- and intramolecular interactions; moreover, it is of particular significance in molecular recognition ${ }^{3}$ and crystal engineering. ${ }^{4}$ The trifluoromethyl group is one of the strategic fluorine-containing substituents and there has been immense interest in its introduction into organic molecules. ${ }^{5,6}$ The discovery of the first electrophilic $\mathrm{CF}_{3}$-transfer agent, by Yagupolskii in $1984,{ }^{7}$ induced new developments in this field. ${ }^{8,9}$ The introduction of the trifluoromethyl group into organic molecules using nucleophilic, $^{10}$ radical $^{11}$ and metal-based ${ }^{12} \mathrm{CF}_{3}$ sources has also progressed very rapidly.

A very attractive modulation of the $\mathrm{CF}_{3}-$ group is $\mathrm{CF}_{3} \mathrm{~S}-$ trifluoromethylthiol group, although its introduction have been studied much less than that of the $\mathrm{CF}_{3}-$ group. The trifluoromethylthiol group $\mathrm{CF}_{3} \mathrm{~S}$ - exhibits a remarkably high lipophilicity parameter, and is one of the key fragments in certain biologically relevant compounds. ${ }^{13}$ The $2^{\prime}-\mathrm{SCF}_{3}$ substituted uridine derivative was found to be a potent label for probing structure and function of RNA by ${ }^{19} \mathrm{~F}$ NMR spectroscopy. ${ }^{14}$ There are different ways of introduction of $\mathrm{CF}_{3} \mathrm{~S}$ - functionality. The

Department of Organic Chemistry, Faculty of Chemistry and Chemical Technology, Večna pot 113, 1001 Ljubljana, Slovenia. E-mail: marjan.jereb@fkkt.uni-lj.si; Fax: +38612419144; Tel: +38614798577

$\dagger$ Electronic supplementary information (ESI) available: Copies of ${ }^{1} \mathrm{H},{ }^{13} \mathrm{C}$ and ${ }^{19} \mathrm{~F}$ NMR spectra of all products, and computed geometries and energies of model species. See DOI: 10.1039/c5ra07316b introduction of the $\mathrm{CF}_{3} \mathrm{~S}$ - group could be performed directly, ${ }^{15}$ by interconversion of functional groups ${ }^{\mathbf{1 6}}$ or by trifluoromethylation of suitable sulfur-containing moieties. ${ }^{17}$ Direct methods usually rely on heavy-metal-based reagents ${ }^{18}$ and/or catalysts or on the use of extremely toxic and hazardous trifluoromethyldisulfide $^{19}$ or trifluoromethylsulfenyl chloride. ${ }^{20}$ Recently, considerable steps forward have been made in the direct introduction of the $\mathrm{CF}_{3} \mathrm{~S}$ - functionality. ${ }^{21}$ Several new $\mathrm{SCF}_{3}$ transfer agents have been developed, particular of an electrophilic nature. The recent progress was initiated by the work of Billard, Langlois and coworkers when they published a synthesis of $\mathrm{PhNHSCF}_{3} 1$ and its derivatives. ${ }^{22}$ These compounds are easyto-handle electrophilic $\mathrm{SCF}_{3}$ reagents that can react with alkenes and alkynes, ${ }^{23}$ indoles,${ }^{24}$ organometallic species, ${ }^{25}$ tryptamines, ${ }^{26}$ amines, ${ }^{27}$ allyl silanes ${ }^{28}$ and phenols. ${ }^{29}$ An interesting cyclization was observed with different internal alkynes and $\mathrm{PhNHSCF}_{3}$ furnishing the corresponding trifluoromethylthio substituted indoles, ${ }^{30}$ benzofurans and benzothiophenes, ${ }^{31} 1 H$-isochromen1-ones, ${ }^{32} 2 H$-benzo[e][1,2] thiazine 1,1-dioxides ${ }^{33}$ and benzofulvenes. $^{34}$ A recently developed trifluoromethanesulfonyl hypervalent iodonium ylide was shown to be an effective trifluoromethylthiolating agent after an in situ reduction of trifluoromethanesulfonyl group. ${ }^{35} \mathrm{~N}$-(Trifluoromethylthio)succinimide was utilized in a selective trifluoromethylthiolation of arenes, ${ }^{36}$ while an in situ-generated reagent from $\mathrm{AgSCF}_{3}$ and NCS was applied for the trifluoromethylthiolation of terminal alkynes. ${ }^{37} \mathrm{~N}$-Trifluoromethylthiophthalimide was employed in trifluoromethylthiolation of boronic acids, ${ }^{38}$ alkynes, ${ }^{39}$ amines and thiols, ${ }^{40}$ and a combination with cinchona alkaloids was utilized in a catalytic asymmetric trifluoromethylthiolation of oxindoles $^{41}$ and $\beta$-ketoesters. ${ }^{42}$ One interesting trifluoromethylthiolating agent is a thioperoxide-based reagent containing a reactive $\mathrm{O}-\mathrm{S}$ bond..$^{\mathbf{4 3 4 4}}$ It was found to be effective in trifluoromethylthiolation of boronic acids, ${ }^{\mathbf{4 5}}$ Grignard reagents, alkynes, indoles, $\beta$-ketoesters, oxindoles, indoles, ${ }^{46}$ sodium 
sulfinates ${ }^{47}$ and carboxylic acids. ${ }^{48}$ It was also utilized in the activation of thioglycoside donors ${ }^{49}$ and in catalytic asymmetric trifluoromethylthiolations. ${ }^{50} \quad \mathrm{~N}$-Trifluoromethylthiosaccharin ${ }^{51}$ was applied in the trifluoromethylthiolation of alcohols, amines, thiols, arenes, ${ }^{52}$ aldehydes, ketones, acyclic $\beta$-ketoesters, and alkynes. Functionalization of allylic alcohols furnished the corresponding trifluoromethyl sulfoxides via a [2,3]sigmatropic rearrangement. ${ }^{53} \mathrm{~A}$ combination of $\mathrm{AgSCF}_{3}$ and trichloroisocyanuric acid was utilized as an in situ electrophilic $\mathrm{SCF}_{3}$ source in enantioselective catalytic functionalization of oxindoles ${ }^{54}$ and in the synthesis of 3-((trifluoromethyl)thio)- $4 H^{-}$ chromen-4-ones. ${ }^{55}$ Carbonyl compounds ${ }^{56}$ and arenes ${ }^{57}$ were trifluoromethylthiolated with a new $N$-((trifluoromethyl)thio) benzenesulfonamide type of reagent.

Trifluoromethyl disulfides are important as precursors of biologically active trifluoromethyl thiosulfonate ${ }^{58,59}$ and can be prepared from thiols ${ }^{60}$ and $\mathrm{CF}_{3} \mathrm{SCl}$ or uncommon pyrole- $\mathrm{SCF}_{3}$ derivatives, ${ }^{61}$ upon reaction of bis(trifluoromethyl) trisulfide and organolithium reagents, ${ }^{62}$ and via the photochemical reaction of trifluoromethylated thioesters with disulfides. ${ }^{63}$ The first of these ${ }^{20}$ is not very convenient or safe, while the latter two methods ${ }^{62,63}$ were neither selective nor synthetically useful. The recently developed reagents $N$-trifluoromethylthiosaccharin ${ }^{51}$ and $N$-trifluoromethylthiophthalimide ${ }^{40}$ were demonstrated to be suitable for the synthesis of trifluoromethyl disulfides. We were interested in the reactivity of $\mathbf{1}$ with thiols because several different transformations are possible. Aromatic ring functionalization could take place; oxidation of thiols into the corresponding disulfides and synthesis of the trifluoromethyl disulfides are the other options. Here, we report on a straightforward, selective and efficient synthesis of trifluoromethyl disulfides.

\section{Results and discussion}

Initially, 4-methylthiophenol $\mathbf{2 a}$ was reacted with $\mathbf{1}$ in dichloromethane (DCM), and only traces of 4-methylphenyl trifluoromethyl disulfide $\mathbf{3 a}$ were noted (Table 1, entry 1). Yields were determined by ${ }^{19} \mathrm{~F}$ NMR spectroscopy using octafluoronaphthalene as internal standard. Structures of the products were further verified independently. It is known that the electrophilic power of $\mathbf{1}$ is not high enough to react without promoters/additives. ${ }^{23}$ Several potential additives in the transformation of $2 \mathbf{a}$ were examined; the results are summarized in Table 1.

Reaction of $2 \mathrm{a}$ with $\mathbf{1}$ in the presence of 2 equivalents of trifluoroacetic anhydride (TFAA) gave $3 \mathrm{a}$ in $51 \%$ yield (entry 2 ). Transformations of $\mathbf{2 a}$ in the presence of some other Lewis acids were not very selective and efficient (entries 3-6). Consequently, we turned our attention to Brønsted acids such as trifluoromethanesulfonic acid (TfOH). Conversion of $\mathbf{2 a}$ in the presence of 0.5 equivalents of $\mathrm{TfOH}$ was only $20 \%$ (entry 7 ). The reaction progressed well in the presence of 1 equivalent of $\mathrm{TfOH}$, however $10 \%$ of $2 \mathrm{a}$ remained unreacted (entry 8 ). Full conversion of $2 \mathrm{a}$ was achieved with 1.2 equivalents of $\mathrm{TfOH}$, and 3a was isolated in good yield (entry 8); while a little amount of $2 \mathrm{a}$ remained unreacted with 1.1 equivalents of
Table 1 Optimization of the reaction conditions ${ }^{a}$

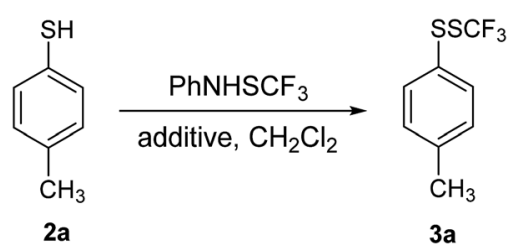

\begin{tabular}{lll}
\hline Entry & Additive/(equiv.) & Yield $^{b}(\%)$ \\
\hline 1 & - & Traces $^{c}$ \\
2 & $\left(\mathrm{CF}_{3} \mathrm{CO}\right)_{2} \mathrm{O} / 2$ & 51 \\
3 & $\mathrm{CF}_{3} \mathrm{COOH} / 2$ & $35^{d}$ \\
4 & $\mathrm{BF}_{3} \cdot \mathrm{Et}_{2} \mathrm{O} / 5$ & $46^{e}$ \\
5 & $\mathrm{TMSOTf}_{2}$ & 57 \\
6 & $\mathrm{Tf}_{2} \mathrm{O} / 2$ & 51 \\
7 & $\mathrm{CF}_{3} \mathrm{SO}_{3} \mathrm{H} / 0.5$ & 20 \\
8 & $\mathrm{CF}_{3} \mathrm{SO}_{3} \mathrm{H} / 1.0$ & 62 \\
9 & $\mathrm{CF}_{3} \mathrm{SO}_{3} \mathrm{H} / 1.2$ & $81[72]^{f}$ \\
10 & $\mathrm{CH}_{3} \mathrm{SO}_{3} \mathrm{H} / 0.5$ & 9 \\
11 & $\mathrm{CH}_{3} \mathrm{SO}_{3} \mathrm{H} / 1.0$ & 38 \\
12 & $\mathrm{CH}_{3} \mathrm{SO}_{3} \mathrm{H} / 1.3$ & $82[72]^{f}$
\end{tabular}

${ }^{a}$ Reaction conditions: $2 \mathrm{a}(0.2 \mathrm{mmol}), \mathbf{1}(0.24 \mathrm{mmol})$, additive, $\mathrm{CH}_{2} \mathrm{Cl}_{2}$ ( $2 \mathrm{~mL}$ ), Ar atmosphere, rt, 12 h. ${ }^{b}$ Yields were determined by ${ }^{19} \mathrm{~F}$ NMR spectroscopy using octafluoronaphthalene as internal standard. ${ }^{c} \mathrm{Di}(4-$ methylphenyl) disulfide was the main product. ${ }^{d}$ Ratio $3 a /$ the disulfide by-product (1.9/1) was determined by ${ }^{1} \mathrm{H}$ NMR spectroscopy. ${ }^{e}$ Ratio 3a/the disulfide by-product (3.5/1) was determined by ${ }^{1} \mathrm{H}$ NMR spectroscopy. ${ }^{f}$ Isolated yield.

TfOH. Methanesulfonic acid (MSA) was tested similarly. Conversion of 2a in the presence of 0.5 equivalents of MSA was as low as $9 \%$ (entry 10 ), while it rose up to $38 \%$ when using 1 equivalent of MSA (entry 11). Transformation of $2 \mathbf{a}$ in the presence of 1.2 equivalents of MSA was almost complete, while full conversion was achieved in the presence of 1.3 equivalents of MSA (entry 12). The product 3a was isolated in a good yield as a sole product. The best reaction selectivity was obtained in entries 9 and 12 yielding 3a only. We decided to use MSA as an additive; however, in some cases better results were obtained with TfOH.

The role of solvent polarity on the reaction course of $2 \mathrm{a}$ with 1 was also examined (Table 2). Functionalization in hexane was completely selective; however, the conversion was not complete (entry 1). Selectivity in toluene was somewhat lower as well as the yield of 3a (entry 2). Diethyl ether would not be a suitable solvent because of low conversion of 2a into 3a (entry 3). Conversion in acetone was good, but some 2a remained unreacted (entry 4). Methanol was a poor solvent for this transformation, since the conversion of 2a remained low (entry 5). In acetonitrile, reaction took place well; however, a part of 2a remained unreacted (entry 6). Functionalization was completely suppressed in water where only traces of $3 \mathbf{a}$ were detected, and 2a and 1 were recovered (entry 7). Interestingly, good yields were obtained in hexane and in acetonitrile in spite of a remarkably different polarity. The protic solvents and water are obviously not suitable for this transformation. Dichloromethane was found to be the best solvent for this reaction (entry 8). 
Table 2 The role of solvent polarity on the reaction course ${ }^{a}$

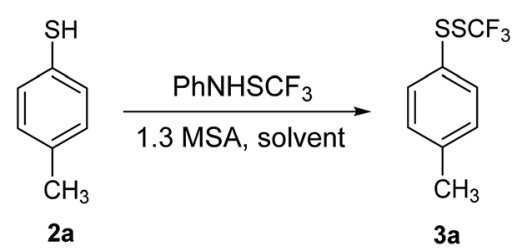

\begin{tabular}{lll}
\hline Entry & Solvent & Yield $^{b}(\%)$ \\
\hline 1 & Hexane & 71 \\
2 & Toluene & 70 \\
3 & Diethyl ether & 36 \\
4 & Acetone & 63 \\
5 & Methanol & 32 \\
6 & Acetonitrile & 62 \\
7 & Water & Traces \\
8 & Dichloromethane & $82[72]^{c}$
\end{tabular}

${ }^{a}$ Reaction conditions: $2 \mathrm{a}(0.2 \mathrm{mmol}), \mathbf{1}(0.24 \mathrm{mmol})$, MSA $(0.26 \mathrm{mmol})$, solvent ( $2 \mathrm{~mL}), \mathrm{Ar}$ atmosphere, rt, $12 \mathrm{~h}$. ${ }^{b}$ Yields were determined by ${ }^{19} \mathrm{~F}$ NMR spectroscopy using octafluoronaphthalene as internal standard. ${ }^{c}$ Isolated yield.

The reactivity of different thiols with $\mathbf{1}$ in dichloromethane under argon atmosphere was tested, and the optimal amount of acid (1.2 and 1.3 equivalents) was used. The results are summarized in Table 3. The model thiol 2a was efficiently

Table 3 Functionalization of aryl thiols with $\mathrm{PhNHSCF}_{3}{ }^{a}$

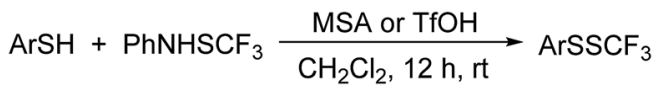

$2 \quad 1 \quad 3$

\begin{tabular}{|c|c|c|c|c|}
\hline Entry & $\mathrm{Ar}$ & Acid/equiv. & 3 & Yield $^{b}(\%)$ \\
\hline 1 & $4-\mathrm{Me}-\mathrm{C}_{6} \mathrm{H}_{4}-2 \mathrm{a}$ & MSA/1.3 & $3 a$ & 82 \\
\hline 2 & $4-\mathrm{OMe}-\mathrm{C}_{6} \mathrm{H}_{4}-2 \mathrm{~b}$ & MSA/1.2 & $3 \mathbf{b}$ & 76 \\
\hline 3 & $4-\mathrm{OH}-\mathrm{C}_{6} \mathrm{H}_{4}-2 \mathrm{c}$ & MSA/1.3 & $3 c$ & 88 \\
\hline 4 & $2-\mathrm{OMe}-\mathrm{C}_{6} \mathrm{H}_{4}-2 \mathrm{~d}$ & MSA/1.2 & $3 d$ & 91 \\
\hline 5 & $2,4-\mathrm{DiMe}-\mathrm{C}_{6} \mathrm{H}_{3}-2 \mathrm{e}$ & MSA/1.2 & $3 e$ & 90 \\
\hline 6 & $2,5-\mathrm{DiMe}-\mathrm{C}_{6} \mathrm{H}_{3}-\mathbf{2 f}$ & MSA/1.3 & $3 f$ & 92 \\
\hline 7 & $3,5-\mathrm{DiMe}-\mathrm{C}_{6} \mathrm{H}_{3}-2 \mathrm{~g}$ & MSA/1.3 & $3 g$ & 89 \\
\hline 8 & $4-i \mathrm{Pr}-\mathrm{C}_{6} \mathrm{H}_{4}-2 \mathbf{h}$ & MSA/1.4 & $3 \mathbf{h}$ & 90 \\
\hline 9 & 2-Naphthyl- 2i & MSA/1.3 & $3 \mathbf{i}$ & 91 \\
\hline 10 & $4-\mathrm{Cl}-\mathrm{C}_{6} \mathrm{H}_{4}-2 \mathrm{j}$ & MSA/1.3 & $3 \mathbf{j}$ & 84 \\
\hline 11 & $4-\mathrm{H}-\mathrm{C}_{6} \mathrm{H}_{4}-2 \mathbf{k}$ & $\mathrm{TfOH} / 1.2$ & $3 \mathbf{k}$ & 75 \\
\hline 12 & $3-\mathrm{OMe}-\mathrm{C}_{6} \mathrm{H}_{4}-2 \mathrm{l}$ & $\mathrm{TfOH} / 1.2$ & 31 & 88 \\
\hline 13 & $4-\mathrm{F}-\mathrm{C}_{6} \mathrm{H}_{4}-2 \mathrm{~m}$ & $\mathrm{TfOH} / 1.2$ & $3 \mathrm{~m}$ & 83 \\
\hline 14 & $2-\mathrm{F}-\mathrm{C}_{6} \mathrm{H}_{4}-2 \mathrm{n}$ & $\mathrm{TfOH} / 1.2$ & $3 n$ & 83 \\
\hline 15 & $2,4-\mathrm{DiF}-\mathrm{C}_{6} \mathrm{H}_{3}-2 \mathrm{o}$ & $\mathrm{TfOH} / 1.2$ & 30 & 80 \\
\hline 16 & $3,4-\mathrm{DiCl}-\mathrm{C}_{6} \mathrm{H}_{3}-2 \mathbf{p}$ & $\mathrm{TfOH} / 1.2$ & $3 p$ & 88 \\
\hline 17 & $2,5-\mathrm{DiCl}-\mathrm{C}_{6} \mathrm{H}_{3}-2 \mathrm{q}$ & $\mathrm{TfOH} / 1.2$ & $3 q$ & 89 \\
\hline 18 & $3-\mathrm{CF}_{3}-\mathrm{C}_{6} \mathrm{H}_{4}-2 \mathbf{r}$ & $\mathrm{TfOH} / 1.2$ & $3 \mathbf{r}$ & 82 \\
\hline 19 & $4-\mathrm{NO}_{2}-\mathrm{C}_{6} \mathrm{H}_{4}-2 \mathrm{~s}$ & $\mathrm{TfOH} / 1.2$ & $3 s$ & 87 \\
\hline
\end{tabular}

${ }^{a}$ Reaction conditions: (a) Thiols $2 \mathbf{a}-2 \mathbf{j}(0.5 \mathrm{mmol}), \mathbf{1}(0.6 \mathrm{mmol})$ and MSA (0.6-0.7 mmol) in DCM $(5 \mathrm{~mL})$ at rt for $12 \mathrm{~h}$ under Ar. Thiols $(2 \mathbf{k}-2 \mathrm{~s})$ were functionalized under the same reaction conditions in the presence of $\mathrm{TfOH}(0.6 \mathrm{mmol}) .{ }^{b}$ Isolated yields. converted into 3a, which was isolated on $0.5 \mathrm{mmol}$ scale in higher yield than on a $0.2 \mathrm{mmol}$ scale (entry 1 , Table 3 ).

The highly activated 4-methoxythiophenol $2 \mathbf{b}$ selectively yielded $\mathbf{3} \mathbf{b}$ in the presence of MSA, whereas $\mathrm{TfOH}$ produced poorer results. A small amount of by-product was formed, which was not isolated, but, as could be judged from the NMR spectra, trifluoromethylthiolation of the aromatic ring took place. The functionalization of 4-hydroxythiophenol 2c, 2-methoxythiophenol 2d and 2,4-dimethylthiophenol 2e smoothly yielded the corresponding trifluoromethyl disulfides $\mathbf{3 c}, \mathbf{3 d}$ and $\mathbf{3 e}$ in the presence of MSA (entries 3-5, Table 3). The less electron-rich 2,5-dimethylthiophenol 2f, 3,5-dimethylthiophenol 2g, 4-i-propylthiophenol 2h, 2-naphthalenethiol $2 \mathbf{i}$ and 4-chlorothiophenol $2 \mathbf{j}$ were selectively converted into their trifluoromethylthio derivatives $\mathbf{3} \mathbf{f}-\mathbf{3} \mathbf{j}$ in the presence of MSA (entries 6-10, Table 3). It was established that thiols bearing electronwithdrawing groups as a rule required stronger activation in comparison with the thiols bearing electron-donating groups. Thiophenol 2k, 3-methoxythiophenol 2l, fluoro-substituted thiophenols 2m-2o and dichloro-substituted thiophenols $\mathbf{2 p}$ and $\mathbf{2 q}$ were transformed into the desired trifluoromethyl disulfides 3k-3q in the presence of $\mathrm{TfOH}$ (entries 11-17, Table 3).

The reactions were selective without substantial formation of other side-products. Functionalization of electron-deficient 3-(trifluoromethyl)thiophenol 2r and 4-nitrothiophenol 2s with 1 took place efficiently in the presence of TfOH yielding the desired products 3r and 3s (entries 18 and 19, Table 2). For illustration, $2 \mathbf{p}$ and $2 \mathbf{s}$ did not react completely in the presence of 1.5 equiv. of MSA, while the full conversion was observed in the presence of 1.2 equiv. of $\mathrm{TfOH}$.

Reactivity of benzyl thiols with 1 was also examined (Table 4). 4-Methoxybenzyl thiol 4a was selectively transformed into its trifluoromethyl disulfide 5a in the presence of MSA (entry 1, Table 4). It was established that benzyl thiols were of higher

Table 4 Transformation of benzylic and aliphatic thiols with $1^{a}$

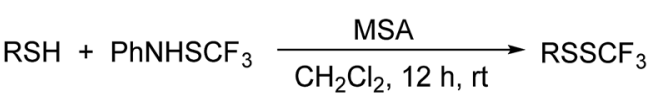
$4 \quad 1$

\begin{tabular}{lllll}
\hline Entry & $\mathrm{R}$ & & $\mathbf{5}$ & Yield $^{b}(\%)$ \\
\hline 1 & $4-\mathrm{MeO}-\mathrm{C}_{6} \mathrm{H}_{4}-\mathrm{CH}_{2}-$ & $\mathbf{4 a}$ & $\mathbf{5 a}$ & 94 \\
2 & $4-\mathrm{H}-\mathrm{C}_{6} \mathrm{H}_{4}-\mathrm{CH}_{2}-$ & $\mathbf{4 b}$ & $\mathbf{5 b}$ & 80 \\
3 & $4-\mathrm{F}-\mathrm{C}_{6} \mathrm{H}_{4}-\mathrm{CH}_{2}-$ & $\mathbf{4 c}$ & $\mathbf{5 c}$ & 78 \\
4 & $4-\mathrm{Cl}-\mathrm{C}_{6} \mathrm{H}_{4}-\mathrm{CH}_{2}-$ & $\mathbf{4 d}$ & $\mathbf{5 d}$ & 87 \\
5 & $3-\mathrm{CF}_{3}-\mathrm{C}_{6} \mathrm{H}_{4}-\mathrm{CH}_{2-}$ & $\mathbf{4 e}$ & $\mathbf{5 e}$ & 93 \\
6 & $\mathrm{Ph}(\mathrm{Me}) \mathrm{CH}-$ & $\mathbf{4 f}$ & $\mathbf{5 f}$ & 58 \\
7 & $n-\mathrm{C}_{8} \mathrm{H}_{17^{-}}$ & $\mathbf{4 g}$ & $\mathbf{5 g}$ & 83 \\
8 & $n-\mathrm{C}_{12} \mathrm{H}_{25^{-}}$ & $\mathbf{4 h}$ & $\mathbf{5 h}$ & 86 \\
9 & $c-\mathrm{C}_{6} \mathrm{H}_{11^{-}}$ & $\mathbf{4 i}$ & $\mathbf{5 i}$ & 57 \\
10 & $-\left(\mathrm{CH}_{2}\right)_{6-}^{-}$ & $\mathbf{4 j}$ & $\mathbf{5 j}$ & 88
\end{tabular}

${ }^{a}$ Reaction conditions: Thiol 4 (0.5 mmol), 1 (0.6 mmol), MSA (0.6-0.65 $\mathrm{mmol}$ ) in DCM ( $5 \mathrm{~mL}$ ) at rt for $12 \mathrm{~h}$ under Ar. Entry 10: $4 \mathbf{j}$ (0.5 mmol), 1 $(1.2 \mathrm{mmol})$, MSA $(1.3 \mathrm{mmol})$ in DCM $(5 \mathrm{~mL})$ at $\mathrm{rt}$ for $12 \mathrm{~h}$ under Ar. ${ }^{b}$ Isolated yields. 
Table 5 Functionalization of sterically hindered and heteroaromatic thiols with $1^{a}$

$$
\mathrm{RSH}+\mathrm{PhNHSCF}_{3} \underset{\mathrm{CH}_{2} \mathrm{Cl}_{2}, 12 \mathrm{~h}, \mathrm{rt}}{\stackrel{\text { acid }}{\longrightarrow}} \mathrm{RSSCF}_{3}
$$

6<smiles>Cc1cc(C)c(S(F)(F)(F)(F)F)c(C)c1</smiles><smiles>FC(F)(F)SC(c1ccccc1)(c1ccccc1)c1ccccc1</smiles>

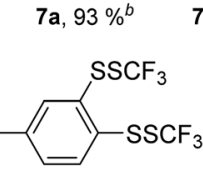

7b, $89 \%$

$7 d, 52 \%$

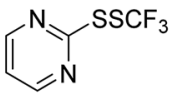

7f, $60 \%$<smiles>FC(F)(F)c1ccccc1-c1ccccc1</smiles>

$7 c, 73 \%$

7

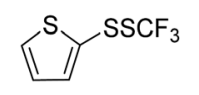

7 e, $53 \%$

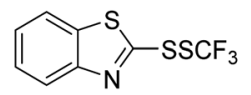

$7 g, 68 \%$
${ }^{a}$ Reaction conditions: Thiol 6 (1.0 equiv.), 1 (1.2 equiv.), acid in DCM at $\mathrm{rt}$ for $12 \mathrm{~h}$ under Ar. Acids: $\mathbf{6 a}$ and $\mathbf{6 b}$ (1.2 equiv. of TfOH). $\mathbf{6 d}$ (1.3 equiv. of TfOH per SH group). $6 \mathbf{c}, 6 \mathbf{6}$ and $6 \mathbf{g}$ (5 equiv. of $p$ TSA $\left.\cdot \mathrm{H}_{2} \mathrm{O}\right) .6 \mathbf{e}(2$ equiv. of MSA). ${ }^{b}$ Isolated yields.

reactivity than thiophenols and MSA was found to be a suitable additive regardless on the substituents. Reactions of benzyl thiols in the presence of $\mathrm{TfOH}$ were much more complex with more unidentified by-products. Benzyl thiol 4b, 4-fluorobenzyl thiol 4c, 4-chlorobenzyl thiol 4d, and 3-(trifluoromethyl)benzyl thiol $4 \mathrm{e}$ were efficiently converted into the corresponding trifluoromethyl disulfides $\mathbf{5 b - 5 e}$ (entries 2-5, Table 4). It is once again obvious, that a relationship for the higher yield exists between the nucleophilicity of the thiols and strength of the promoter, i.e. strongly nucleophilic thiols require milder activation. 1-Phenylethanethiol $\mathbf{4 f}$ was detected in a peel oil extract of Pontianak oranges as a mixture of enantiomers $((R):(S))=$ $76: 24$, and it contributes to the characteristic odor of this citrus fruit. The compound has a very low odour threshold of $0.005 \mathrm{ng}$ $\mathrm{L}^{-1}$ in the air. ${ }^{64}$ Functionalization of racemic $\mathbf{4 f}$ with $\mathbf{1}$ in the presence of MSA led to the desired product $\mathbf{5 f}$ (entry 6, Table 4).

Some aliphatic thiols were also examined in reaction with $\mathbf{1}$. As could have been anticipated, the suitable additive was MSA. 1-Octanethiol $\mathbf{4 g}$ and 1-dodecanethiol $\mathbf{4 h}$ selectively furnished the related trifluoromethyl disulfides $\mathbf{5 g}$ and $\mathbf{5 h}$ (entries 7 and 8 , Table 4). The reaction of cyclohexanethiol $4 \mathbf{i}$ yielded the corresponding product $5 \mathbf{i}$ in a reasonable yield (entry 9, Table 4). 1,6-Hexanedithiol $\mathbf{4 j}$ was tested, and double functionalization took place, thus yielding $5 \mathbf{j}$ in a high yield (entry 10 , Table 4 ).

Furthermore, we focused on the reactivity of sterically hindered- and heteroaromatic thiols (Table 5). 2,4,6-Trimethylthiophenol 6a was successfully converted into trimethyl disulfide 7a in the presence of $\mathrm{TfOH}$, while MSA was not an effective promoter. A remarkably sterically hindered thiol group in triphenylmethanethiol $\mathbf{6 b}$ was efficiently functionalized in the presence of $\mathrm{TfOH}$, and product $7 \mathbf{b}$ was isolated in a high yield. 2-Phenylthiophenol $\mathbf{6 c}$ gave the expected trifluoromethyl disulfide $7 \mathbf{c}$ in the presence of 5 equiv. of $p$-toluenesulfonic acid hydrate. 4-Methyl-1,2-benzenedithiol $6 \mathbf{d}$ possesses two adjacent thiol groups, and both were functionalized with 1 in the presence of TfOH giving $\mathbf{7 d}$.

The transformation of 2-thiophenethiol 6e into 7e occurred in the presence of MSA, while selectivity dropped remarkably in the presence of TfOH. 2-Mercaptopyrimidine $6 \mathbf{f}$ and

Table 6 Functionalization of the acid sensitive and biologically important thiols ${ }^{a}$

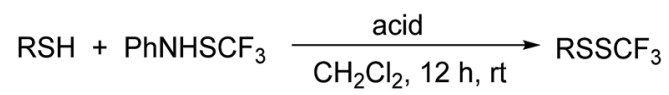

8

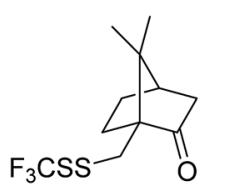

$\mathrm{F}_{3} \mathrm{CSS}$<smiles>Cc1ccc2c(C)cc(=O)oc2c1</smiles>

$9 b, 77 \%$<smiles>O=C(Oc1ccccc1)c1ccc(F)cc1</smiles>

$9 e, 37 \%$<smiles>CCOC(=O)[C@H](CS(F)(F)F)NC(C)=O</smiles>

9f, $58 \%$<smiles>O=C(CSc1ccccc1)Nc1ccc(Br)cc1</smiles><smiles>O=C(CSc1ccccc1)c1ccccc1</smiles>

$9 c, 30 \%$

$9 d, 39 \%$

\footnotetext{
${ }^{a}$ Reaction conditions: Thiol 8 (1 equiv.), $\mathbf{1}$ (1.2 equiv.), acid in DCM at rt for $12 \mathrm{~h}$ under Ar. Acids: $\mathbf{8 a}, \mathbf{8 c}$ and $8 \mathbf{e}(1.3$ equiv. of TfOH). $8 \mathbf{b}$ and $8 \mathbf{g}$ (1.2 equiv. of TfOH). 8d ( 5 equiv. of $\left.\mathrm{BF}_{3} \cdot \mathrm{Et}_{2} \mathrm{O}\right) .8 \mathrm{8f}\left(1.2\right.$ equiv. of MSA). ${ }^{b}$ Isolated yields.
} 
2-mercaptobenzothiazole $\mathbf{6 g}$ were converted into the related trifluoromethyl disulfides $7 \mathbf{f}$ and $7 \mathbf{g}$ in the presence of 5 equiv. of $p$-toluenesulfonic acid hydrate. It could be concluded that sterically hindered- and heteroaromatic thiols could be effectively functionalized with 1.

Next, we turned our attention to the structurally diverse, acid-sensitive and biologically important thiols (Table 6). It is known that the camphor skeleton could undergo an acidcatalyzed rearrangement, and it is frequently used in organocatalysis as well as a chiral auxiliary. ( \pm )-7,7-Dimethylbicyclo-1(mercaptomethyl)bicyclo[2.2.1] heptan-2-one $8 \mathrm{a}$ yielded the expected trifluoromethyl disulfide 9a in the presence of $\mathrm{TfOH}$, and no rearrangement was noted.

This is a significant indication that the applied acidic reaction conditions turned to be compatible with acid-labile substrates. 7-Mercapto-4-methylcoumarin $8 \mathbf{b}$ was selectively converted into $3 \mathbf{j}$ in the presence of $\mathrm{TfOH}$ in spite of the presence of the acid-labile lactone group. Amide $\mathbf{8 c}$ was converted into $9 \mathrm{c}$ in the presence of $\mathrm{TfOH}$ in a moderate yield. The functionalization of 2-mercapto-1-phenylethanone 8d with $\mathbf{1}$ in the presence of $\mathrm{BF}_{3} \cdot \mathrm{Et}_{2} \mathrm{O}$ led to the related $\alpha$-trifluoromethyldisulfido ketone 9d. The reaction of thiobenzoic acid $\mathbf{8 e}$ in the presence of $\mathrm{TfOH}$ produced $\mathbf{9 e}$, although it was isolated in a moderate yield.

In addition, we examined the reactivity of two biologically relevant thiols, i.e. the protected cysteine derivative $8 \mathbf{f}$ and 1thioglucose derivative $\mathbf{8 g}$. The both substrates are particularly challenging because of the acidic reaction conditions. The functionalization of $\mathbf{8 f}$ proceeded completely in the presence of 1.2 equiv. of MSA, and 9f was obtained in a 58\% yield. The reaction of $8 \mathrm{~g}$ in the presence of 1.2 equiv. of MSA took place smoothly; however, two sets of signals were observed in ${ }^{1} \mathrm{H}$ NMR spectrum. Interestingly, the transformation of $\mathbf{8 g}$ in the presence of 1.2 equivalents of $\mathrm{TfOH}$ furnished a single stereoisomer $\mathbf{9 g}$, and no epimerization took place. We were pleased that protecting groups were compatible with the acidic reaction conditions and that epimerization in the case of $\mathbf{8 g}$ could be avoided.

There is hardly any mention of trifluoromethyl thiosulfonates in the literature. ${ }^{65}$ Recently, an efficient synthetic method starting from sodium sulfonates was published. ${ }^{47}$ Thiosulfonates possess different biological activities ${ }^{58,59}$ and could be utilized as sulfenylating agents. ${ }^{66}$ Upon reaction with $\mathbf{1}$ in the presence of 5 equiv. of $p$ TSA $\cdot \mathrm{H}_{2} \mathrm{O}$, sodium sulfinates 10a and 10b produced the corresponding trifluoromethyl thiosulfonates 11a and 11b in high yields (Scheme 1).

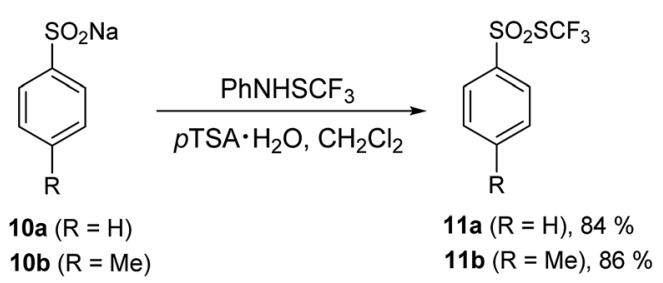

Scheme 1 Transformation of sodium sulfinates with $\mathrm{PhNHSCF}_{3}$.

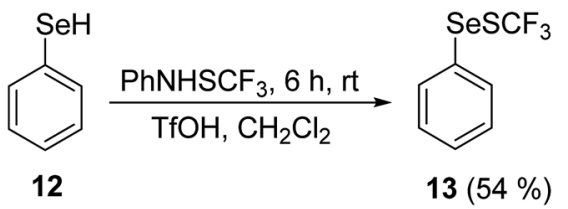

Scheme 2 Reaction of benzeneselenol 12 with $\mathrm{PhNHSCF}_{3}$.

Additionally, the reactivity of the selenium analog 12 was examined (Scheme 2). Benzeneselenol 12 reacted fully with 1 in the presence of 1.5 equivalents of MSA, giving product 13 and a substantial amount of diphenyl diselenide.

The reaction of $\mathbf{1 2}$ in the presence of 1.2 equiv. of $\mathrm{TfOH}$ was considerably more selective, and phenylselenyl(trifluoromethyl) sulfide 13 was obtained as the sole product. The starting material 12 already contained a small amount of diphenyl diselenide; however, no appreciable additional oxidation of $\mathbf{1 2}$ took place.

The $\mathrm{SSCF}_{3}$ group is a relatively strong electron-withdrawing group, and the reactivity of trifluoromethyl disulfides is substantially unexplored. We were interested in how the $\mathrm{SSCF}_{3}$ group affects the reactivity of the aromatic ring. A model disulfide 3a was reacted with a mixture of concentrated $\mathrm{HNO}_{3}$ / $\mathrm{H}_{2} \mathrm{SO}_{4}$ at $50{ }^{\circ} \mathrm{C}$ (Scheme 3).

Trace amounts of the 3-nitro regioisomer were also detected in the crude reaction mixture. No oxidation of the sulfur atoms or of the methyl group was noted, while nitration took place, furnishing 2-nitro derivative $\mathbf{1 4}$ as the main product.

\section{Mechanism}

A detailed reaction mechanism is not known, although several conclusions could be drawn. The relative reactivity of the arylsubstituted thiols with 1 was determined, and a slope of the Hammett linear free energy relationship was obtained to be $\rho=$ -1.65 with a good correlation $\left(r^{2}>0.95\right)$ (Fig. 1).

The more electron-deficient thiols are of lower reactivity than the electron-rich ones, thus indicating that the electron density on the sulfur atom is more important than the acidity of the starting thiol. The Hammett correlation indicated that an important amount of the positive charge was developed in the transition state. The formation of the thiolate anion under the acidic reaction conditions was likely not to be a significant process, but thiols remained in the molecular form that is presumably able to react with the activated form of the reagent 1. An unactivated reagent 1 is essentially an amine of relatively low electrophilic power. The acid seemingly protonates $\mathbf{1}$ on the

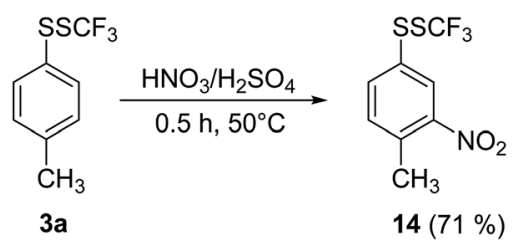

Scheme 3 Functionalization of $3 a$ with $\mathrm{HNO}_{3} / \mathrm{H}_{2} \mathrm{SO}_{4}$. 


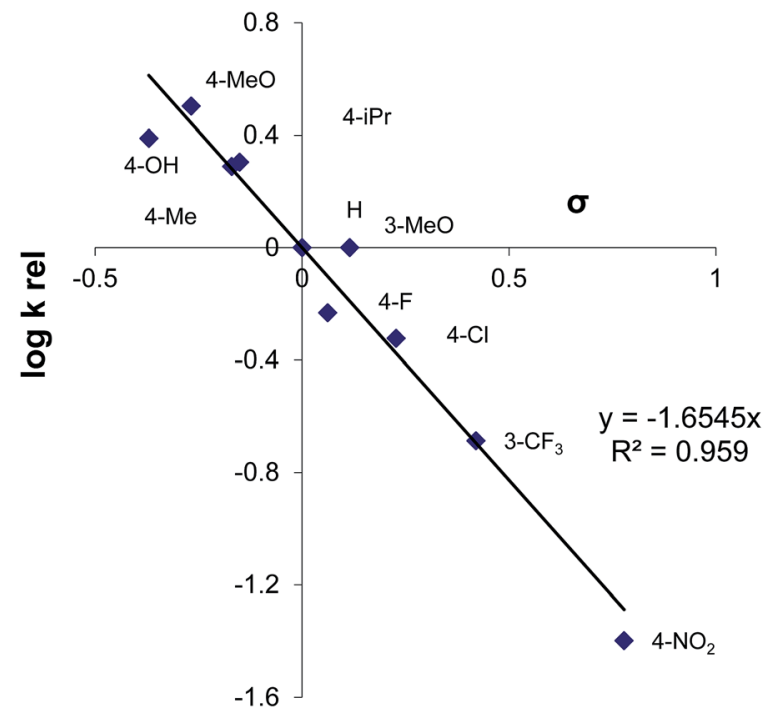

Fig. 1 Hammett correlation for functionalization of the arylsubstituted thiols with 1 .

nitrogen atom, thus generating a species of higher electrophilicity, able to react with thiols as nucleophiles. The reaction of 2a with $1 / \mathrm{TfOH}$ was examined in the presence of TEMPO, and the full conversion of 2a into 3a was noted. The yield of the product was practically the same as without TEMPO, and radicals are not likely to be important reaction intermediates. ${ }^{9 e}$

Some additional experiments were performed in order to get a deeper insight into a reaction mechanism. The acid has a double role in this transformation; it acts as a promoter and as a reagent, since one of the final products is a salt of an aromatic amine. Reagent 1 was dissolved in $\mathrm{CDCl}_{3}$ and separately treated with MSA and TfOH in two NMR tubes. 1 reacted fully with TfOH immediately, and an instantaneous downfield shift of one major and two minor singlets appeared in the ${ }^{19} \mathrm{~F}$ NMR spectrum. This is an indication that protonation of $\mathbf{1}$ occurred, moreover it appears that there was an equilibrium between several species. On the contrary, reaction of $\mathbf{1}$ and MSA was far from completion after five minutes at room temperature; however there appeared three downfield shifted singlets in the ${ }^{19} \mathrm{~F}$ NMR spectrum, indicating a partial protonation of $\mathbf{1}$. MSA is likely too weak to protonate $\mathbf{1}$ in a weakly polar medium to an appreciable extent. The subsequent addition of 2a to both NMR tubes resulted in an immediate formation of $\mathbf{3 a}$ in both cases. In the case of TfOH, the activated form of $\mathbf{1}$ was already present, while addition of 2a in the case of MSA was a driving force to shift equilibrium with the activated form of $\mathbf{1}$ completely in the direction of formation of 3a. Based on the Hammett $\rho$ value, we proposed a reaction of the protonated $\mathbf{1}$ with thiol as a nucleophilic substitution on the sulfur atom in a bimolecular reaction.

To elucidate further the reaction course, the quantum chemical calculations were performed. 1, methanethiol and methanesulfonic acid were chosen as a model system. Since the formation of ionic intermediates and/or transition states was proposed, calculations in vacuum would give erroneous results, therefore all calculations were carried out for species in dichloromethane solution, using the Poisson-Boltzmann model. Still, when energies of the participating species were computed individually, some computed energies were unrealistically high. In poorly polar medium, such as dichloromethane, extensive ion pairing exists, and when this was taken into account, a more realistic picture was obtained, presented in Fig. 2.

The reaction is, according to calculations, a two-step (A + D) nucleophilic substitution, starting with attack of thiol to a protonated amine. In the first step of the reaction, an intermediate is formed in a shallow depression. In this step, no appreciable activation barrier was found. The central $\mathrm{S}$ atom in the intermediate bears formally ten valence electrons, which causes the N-S-S bonding to be essentially a 3c-4e (hypervalent) bond. This is reflected in elongated bonds, nearly linear arrangement of $\mathrm{N}-\mathrm{S}-\mathrm{S}$ atoms and typical charge distribution (see ESI $\dagger$ ). In the intermediate and the transition state a charge of +0.561 and +0.775 a.u. (NBO), respectively, appears on methanethiol moiety, which is in accordance with value of the measured Hammett $\rho$ constant. The process in and around the transition state is essentially a movement of sulfonate anion,

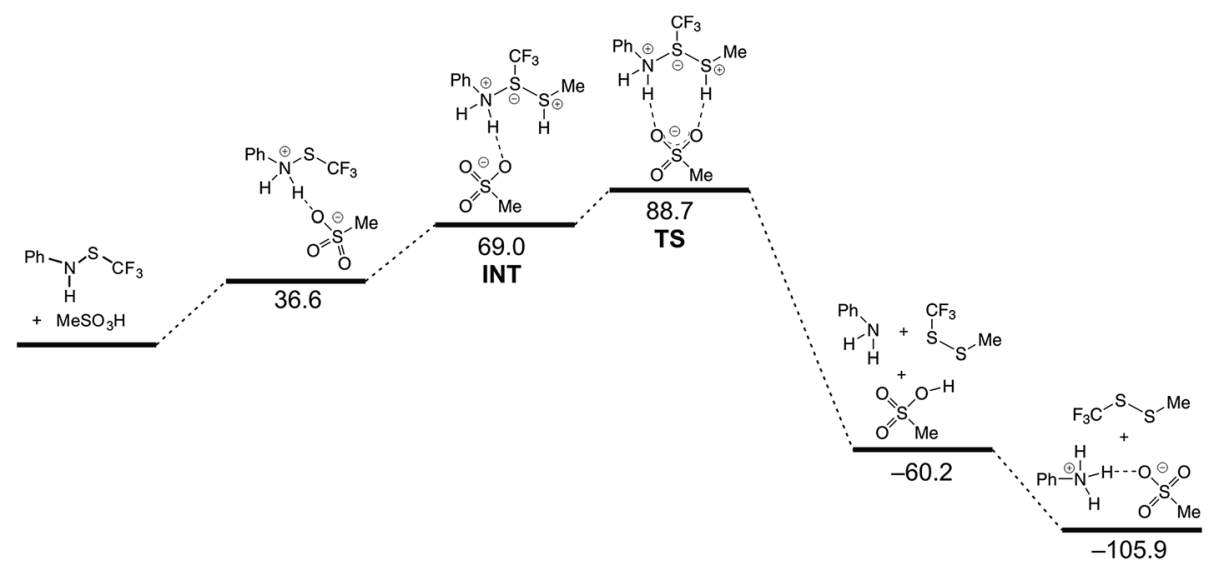

Fig. 2 Energy diagram of the reaction of $N$-[(trifluoromethyl)thio]aniline with methanethiol and methanesulfonic acid in dichloromethane, computed at MPW1K/6-311+G** level. Enthalpies in $\mathrm{kJ} \mathrm{mol}^{-1}$, in first two structures methanethiol is omitted. 


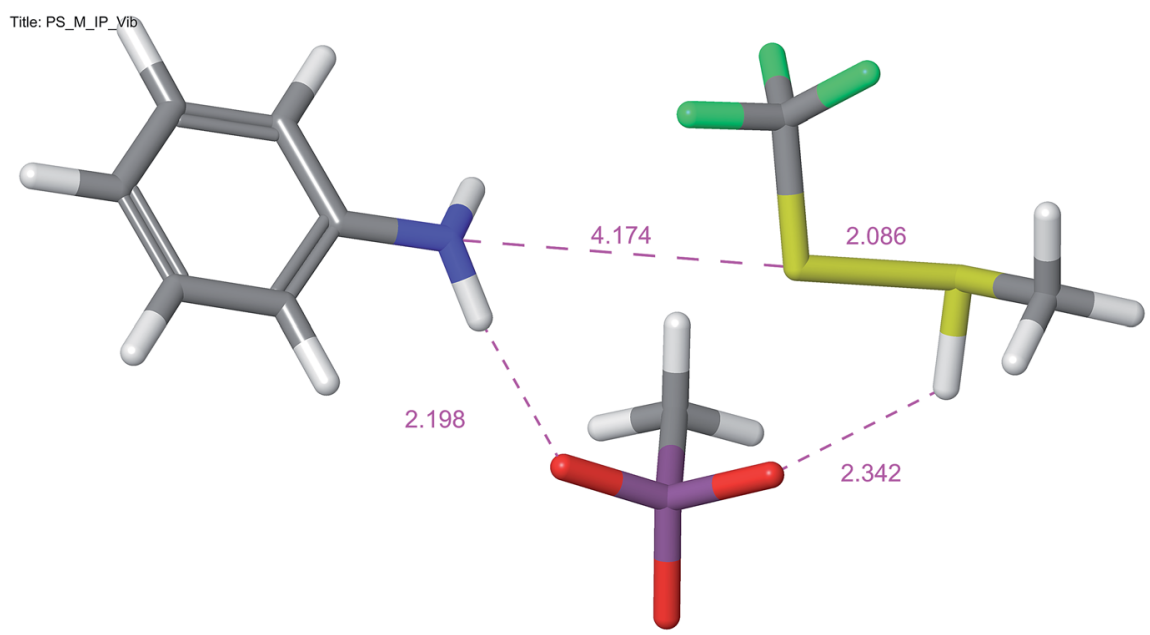

Fig. 3 Transition state for the nucleophilic substitution on the sulfur atom of 1 with methanethiol, MPW1K/6-311+G**.

attached initially to an $\mathrm{N}-\mathrm{H}$ proton, towards the S-H proton. Removal of the latter proton causes simultaneous cleavage of the $\mathrm{NH}-\mathrm{O}$ and $\mathrm{N}-\mathrm{S}$ bonds and disintegration of the aggregate into products (Fig. 3).

\section{Conclusions}

The reactivity of the electrophilic trifluoromethylthiolating reagent $\mathrm{PhNHSCF}_{3}$ was tested on aryl-, benzyl-, alkyl-, heteroaryl-, sterically hindered-, biologically relevant- and acid sensitive thiols in the presence of acidic additives. The aryl-substituted thiols reacted well, regardless of the nature of the substituents. Trifluoromethyl disulfides were obtained as the sole products, no aromatic ring functionalization or parent disulfides formation were noted. Some acid-sensitive substrates were efficiently functionalized, thus proving compatibility with the acidic reaction conditions. The more electron-rich thiophenols required milder activation (methanesulfonic acid), and the more electron-deficient thiols required triflic acid. The nucleophilicity of the starting thiols appears to be of higher importance than their acidity. Sodium sulfonates were demonstrated to be suitable substrates for the synthesis of trifluoromethyl thiosulfonates using $\mathbf{1}$ and $p$-toluenesulfonic acid hydrate as an additive. Benzeneselenol was conveniently transformed into $\mathrm{PhSeSCF}_{3}$, a novel type of selenium compounds. The reactivity of trifluoromethyl disulfide product 3a with $\mathrm{HNO}_{3} / \mathrm{H}_{2} \mathrm{SO}_{4}$ was examined. Nitration of the aromatic ring took place, and no oxidation of sulfur atoms or methyl group was observed. The Hammett correlation analysis on the functionalization of the substituted thiophenols revealed the formation of the electrondeficient intermediate $\rho=-1.65$. MSA or TfOH most likely protonated 1 and enhanced its reactivity due to the stronger polarization between sulfur and nitrogen atoms. The generated sulfur electrophile is then able to react with thiols. Reactions in the presence of free radical TEMPO revealed that radicals are not very likely to be important reaction intermediates. The quantum chemical calculations indicated protonation of $\mathbf{1}$ in the initial stage, followed by a nucleophilic attack of thiol to the protonated 1, forming an intermediate, which decomposes through a transition state in which the sulfonate anion, attached initially by hydrogen bonding to an $\mathrm{N}-\mathrm{H}$ proton, approaches the S-H proton. Removal of the S-H proton brings about an instantaneous collapse of the transition aggregate into products. In the intermediate and transition state a considerably positive charge is formed on the thiol moiety, which is in a good agreement with the Hammett correlation study.

\section{Experimental section}

\section{General information}

All reactions were carried under an argon atmosphere with stirring at room or elevated temperature. Dichloromethane (>99.9\%) was used as received. Most of thiols, benzeneselenol, other catalysts and acids were obtained from commercial sources and used as received.

Crude trifluoromethylthiolated products were purified by column chromatography on silica gel (63-200 $\mu \mathrm{m}, 70-230$ mesh ASTM; Fluka) using hexane or hexane/diethyl ether. TLC was performed on Merck-60- $\mathrm{F}_{254}$ plates using mixtures of hexane and diethyl ether. The melting points were determined in opencapillaries on Büchi 535 apparatus and are uncorrected. All products were characterized by their ${ }^{1} \mathrm{H}$ NMR, ${ }^{19} \mathrm{~F}$ NMR, ${ }^{13} \mathrm{C}$ NMR spectra, IR, HRMS and/or elemental analysis. HRMS data were obtained on Agilent 6224 Accurate Mass TOF LC/MS instrument (ESI-TOF) at Infrastructure Centre at UL FCCT in Ljubljana and on Thermo Scientific Q-Exactive spectrometer with Ion Max ion source equipped with a Syagen Technology PhotoMate Krypton lamp (APCI and APPI with orbitrap mass analyzer) in the Central Laboratory for Environmental, Plant \& Microbial Metabolomics at the Karl-Franzens-University in Graz. The ${ }^{1} \mathrm{H}$ and ${ }^{13} \mathrm{C}$ NMR spectra were recorded on Bruker Avance 300 DPX, Bruker Avance III 500, and on Varian System $600 \mathrm{MHz}$ instruments. The ${ }^{19} \mathrm{~F}$ NMR spectra were only recorded on Bruker Avance III 500 instrument. Chemical shifts are reported in $\delta(\mathrm{ppm})$ values relative to the TMS $(\delta=0.00 \mathrm{ppm})$ and to the residual $\mathrm{CHCl}_{3}(\delta=7.26 \mathrm{ppm})$ for ${ }^{1} \mathrm{H}$ NMR, to the 
central line of $\mathrm{CDCl}_{3}(\delta=77.0 \mathrm{ppm})$ and to the central line of acetone- $\mathrm{d}_{6}(\delta=30.83 \mathrm{ppm})$ for ${ }^{13} \mathrm{C}$ NMR. ${ }^{19} \mathrm{~F}$ NMR spectra are referred to $\mathrm{CFCl}_{3}(\delta=0.00 \mathrm{ppm})$.

Computational details. For DFT calculations, all structures are fully optimized on MPW1K/6-311+G** level of theory. B3LYP functional gives similar results, however MPW1K was chosen because it is better suited for structures with elongated bonds and transition states. ${ }^{67}$ All geometries were optimized for species in dichloromethane solution, using Poisson-Boltzmann model. Vibrational frequencies were calculated in vacuum on solution-optimized structures. Atomic charges were calculated using NBO analysis. ${ }^{68}$ All calculations were run on Jaguar, Schrödinger Release 2014-4: Jaguar, version 8.6, Schrödinger, LLC, New York, NY, 2014.

Preparation of 1 and starting thiols. $N$-[(Trifluoromethyl)thio]aniline $\mathbf{1}$ was prepared according to the published procedure. $^{22}$ 8f was prepared from L-cysteine ethyl ester hydrochloride, ${ }^{69}$ and $\mathbf{8 g}$ was prepared according to the known method. ${ }^{70}$ KSAc was prepared according to the published procedure. ${ }^{71}$ 2-Mercapto-1-phenylethanone $8 \mathbf{d}$ was prepared from 2-bromoacetophenone in two steps. ${ }^{72}$ The first step was modified, while the literature procedure was followed in the second step. The first step: to a solution of 2-bromoacetophenone (15 mmol, $3.0 \mathrm{~g}$ ) in DMF (20 mL) KSAc $(20.9 \mathrm{mmol}$, $2.39 \mathrm{~g}$ ) was added and the mixture was stirred for $2 \mathrm{~h}$ at room temperature (TLC indicated consumption of the starting ketone). The reaction mixture was diluted with water $(30 \mathrm{~mL})$ and the product extracted with diethyl ether $(3 \times 30 \mathrm{~mL})$. The ethereal phase was washed with water, dried over anhydrous $\mathrm{Na}_{2} \mathrm{SO}_{4}$, and the solvent evaporated. The thus-obtained crude 2-acetylthioacetophenone was transformed into 2-mercapto-1phenylethanone $\mathbf{8 d}$, according to the published procedure. ${ }^{72}$ $( \pm)$-1-Phenylethanethiol $\mathbf{4 f}$ and $( \pm)$-10-thiocamphor 8a were prepared according to the published procedure. ${ }^{73} \mathrm{~N}-(4$ Bromophenyl)-2-mercaptoacetamide 8c was prepared in three steps, starting from 4-bromoaniline (20 mmol, $3.44 \mathrm{~g}$ ), and bromoacetyl bromide thus producing $N$-(4-bromophenyl)-2bromoacetamide (13.9 mmol, $4.08 \mathrm{~g}$ ) according to the published procedure. ${ }^{74}$ In the second step, $\mathrm{N}$-(4-bromophenyl)-2bromoacetamide was reacted with KSAc in DMF as described above, and $\mathrm{N}$-(4-bromophenyl)-2-thioacetylacetamide (10.2 mmol, $2.9 \mathrm{~g}$ ) was isolated in the same way as described above in the case of $\mathbf{8 d}$. In the last step, the crude $N$-(4-bromophenyl)2-thioacetylacetamide was dissolved in a mixture of diethyl ether $(10 \mathrm{~mL})$ and THF $(15 \mathrm{~mL})$ and $20 \mathrm{~mL}$ of aqueous solution of $\mathrm{NaOH}$ (50 mmol, $2 \mathrm{~g}$ ) was added. The mixture was stirred vigorously for $2 \mathrm{~h}$ at room temperature (TLC indicated consumption of the starting material). The reaction mixture was acidified with a $37 \%$ aqueous solution of $\mathrm{HCl}(3 \mathrm{~mL})$ to acidic $\mathrm{pH}$. The product was extracted with dichloromethane $(3 \times 20 \mathrm{~mL})$, washed twice with water and dried over anhydrous $\mathrm{Na}_{2} \mathrm{SO}_{4}$, and the solvent evaporated. Yellowish crystals of $\mathrm{N}$-(4-bromophenyl)-2-mercaptoacetamide ${ }^{75} 8 \mathrm{c}$ were purified by crystallization from dichloromethane/hexane. 2-Phenylbenzenethiol $^{76}$ 6c was prepared according to the published procedure. ${ }^{77}$ 10a and $10 \mathrm{~b}$ were prepared according to the known procedure. ${ }^{78}$

\section{Representative procedure for the trifluoromethylthiolation of} thiols with PhNHSCF $_{3}$

To a solution of 4-methybenzenethiol $2 \mathrm{a}(0.5 \mathrm{mmol}, 62 \mathrm{mg})$ in dichloromethane $(5 \mathrm{~mL}), \quad N$-[(trifluoromethyl)thio]aniline 1 (0.6 mmol, $116 \mathrm{mg}$ ) and trifluoromethanesulfonic acid (0.65 mmol, $63 \mathrm{mg}$ ) were added and the mixture was stirred under argon for $12 \mathrm{~h}$. The mixture was diluted with $15 \mathrm{~mL}$ of $\mathrm{CH}_{2} \mathrm{Cl}_{2}$, washed with aqueous solution of $\mathrm{NaHCO}_{3}$, water and dried over anhydrous $\mathrm{Na}_{2} \mathrm{SO}_{4}$. After filtration, the solvent was evaporated and the crude reaction mixture was analyzed by ${ }^{1} \mathrm{H}$ and ${ }^{19}$ F NMR spectroscopy. Pure product 3a as yellow oil (92 mg, $82 \%$ ) was obtained after column chromatography on silica gel using hexane as eluent.

The same procedure was used also in the case of benzeneselenol 12.

\section{Experimental procedure for nitration of 3a}

$65 \%$ nitric acid (3.1 mmol, $300 \mathrm{mg}$ ) and $98 \%$ sulfuric acid (1.5 mmol, $150 \mathrm{mg}$ ) were added to $3 \mathrm{a}(0.6 \mathrm{mmol}, 135 \mathrm{mg})$, and the mixture was stirred at $50{ }^{\circ} \mathrm{C}$ for 30 minutes. Full consumption of $\mathbf{3 a}$ was noted by TLC. The reaction mixture was cooled to rt, diluted with $15 \mathrm{~mL}$ of dichloromethane washed with aqueous solution of $\mathrm{NaHCO}_{3}$, water and dried over anhydrous $\mathrm{Na}_{2} \mathrm{SO}_{4}$. After filtration, the solvent was evaporated and the crude reaction mixture was analyzed by ${ }^{1} \mathrm{H}$ and ${ }^{19} \mathrm{~F}$ NMR spectroscopy. Pure product 14 as yellow solid (114 mg, 71\%) was obtained after column chromatography on silica gel using hexane/diethyl ether $(1 / 10)$ as eluent.

\section{Determination of the relative reactivity of the substituted thiophenols in the Hammett correlation analysis}

The relative rates of substituted thiophenols (Fig. 1) were determined by competitive reactions as follows: to a mixture of two substrates (reference $\mathrm{PhSH}(0.2 \mathrm{mmol})$ and the examined substituted thiophenol (0.2 mmol) $), \mathrm{PhNHSCF}_{3}(0.2 \mathrm{mmol})$ and MSA or TfOH (0.24-0.26 mmol) were added, and the mixture was stirred for $12 \mathrm{~h}$ at $\mathrm{rt}$. The reaction was quenched with water, and products were extracted with DCM $(2 \times 10 \mathrm{~mL})$ and washed with water. The phases were separated and the organic layer was dried over anhydrous $\mathrm{Na}_{2} \mathrm{SO}_{4}$. The solvent was removed under reduced pressure, and the reaction mixture was analyzed by ${ }^{19} \mathrm{~F}$ NMR. Octafluoronaphthalene was used as internal standard. The difference in reactivity of $\mathrm{PhSH}$ and 4-nitrothiophenol was too high to obtain reliable $k_{\text {rel }}$ in this manner. For this reason, 4-chlorothiophenol was taken as a second reference molecule for 4-nitrothiophenol. The relative reactivity of 4-nitrothiophenol vs. PhSH was therefore determined indirectly: $k(4-$ $\left.\mathrm{NO}_{2}\right) / k(4-\mathrm{H})$ was obtained from: $k(4-\mathrm{Cl}) / k(4-\mathrm{H})$ and $k(4-\mathrm{Cl}) / k(4-$ $\mathrm{NO}_{2}$ ). Relative reactivities expressed by the relative rate factors $k_{\mathrm{R}}$ were calculated from the equation ${ }^{79} k_{\mathrm{R}}=k_{A} / k_{B}=\log ((A-X) /$ $A) / \log ((B-Y) / B)$, derived from the Ingold-Shaw relation, ${ }^{\mathbf{8 0}}$ where $A$ and $B$ are the amounts of starting material and $X$ and $Y$ the amounts of products derived from them. The relative rate factors thus obtained, presented in Fig. 1, are the averages of at least three measurements. 
1-Methyl-4-((trifluoromethyl)sulfinothioyl)benzene (3a).$^{51}$ (0.5 mmol of $2 \mathrm{a}, 0.6 \mathrm{mmol}$ of $\mathbf{1}, 0.65 \mathrm{mmol}$ of MSA). Yellow oil (92 mg, 82\%). ${ }^{1} \mathrm{H} \mathrm{NMR}\left(\mathrm{CDCl}_{3}\right): \delta 2.37(\mathrm{~s}, 3 \mathrm{H}), 7.15-7.20(\mathrm{~m}, 2 \mathrm{H})$, 7.47-7.52 (m, 2H); ${ }^{19} \mathrm{~F} \mathrm{NMR}\left(\mathrm{CDCl}_{3}\right): \delta-46.3\left(\mathrm{~s}, \mathrm{SCF}_{3}\right) ;{ }^{13} \mathrm{C} \mathrm{NMR}$ $\left(\mathrm{CDCl}_{3}\right): \delta 21.2,129.3\left(\mathrm{q}, J=313.9 \mathrm{~Hz}, \mathrm{SCF}_{3}\right), 130.2,131.2,131.5$, 139.8. IR (neat) $\mathrm{cm}^{-1}: 1140,1096,804,751$. HRMS: (APCI + PI) calcd for $\mathrm{C}_{8} \mathrm{H}_{7} \mathrm{~F}_{3} \mathrm{~S}_{2}$ 223.9936, found 223.9927.

1-Methoxy-4-((trifluoromethyl)sulfinothioyl)benzene (3b). ( $0.5 \mathrm{mmol}$ of $2 \mathbf{b}, 0.6 \mathrm{mmol}$ of $\mathbf{1}, 0.6 \mathrm{mmol}$ of MSA). Yellow oil (91 $\mathrm{mg}, 76 \%) .{ }^{1} \mathrm{H}$ NMR $\left(\mathrm{CDCl}_{3}\right): \delta 3.83(\mathrm{~s}, 3 \mathrm{H}), 6.87-6.91(\mathrm{~m}, 2 \mathrm{H})$, 7.54-7.59 (m, 2H); ${ }^{19} \mathrm{~F} \mathrm{NMR}\left(\mathrm{CDCl}_{3}\right): \delta-46.2\left(\mathrm{~s}, \mathrm{SCF}_{3}\right) ;{ }^{13} \mathrm{C} \mathrm{NMR}$ $\left(\mathrm{CDCl}_{3}\right): \delta 55.4,115.0,125.3,129.5\left(\mathrm{q}, J=313.6 \mathrm{~Hz}, \mathrm{SCF}_{3}\right), 134.8$, 161.2. IR (neat) $\mathrm{cm}^{-1}: 1590,1492,1291,1250,1137,1095,1031$, 826, 751. HRMS: (APCI + PI) calcd for $\mathrm{C}_{8} \mathrm{H}_{7} \mathrm{~F}_{3} \mathrm{OS}_{2}$ 239.9885, found 239.9876 .

1-Hydroxy-4-((trifluoromethyl)sulfinothioyl)benzene (3c). ( $0.5 \mathrm{mmol}$ of $2 \mathrm{c}, 0.6 \mathrm{mmol}$ of $1,0.65 \mathrm{mmol}$ of MSA). Yellow oil (99 mg, 88\%). ${ }^{1} \mathrm{H} \mathrm{NMR}\left(\mathrm{CDCl}_{3}\right): \delta 5.27$ (br s, $\left.1 \mathrm{H}\right), 6.79-6.86(\mathrm{~m}$, 2H), 7.48-7.55 (m, 2H); ${ }^{19} \mathrm{~F} \mathrm{NMR}\left(\mathrm{CDCl}_{3}\right): \delta-46.2\left(\mathrm{~s}, \mathrm{SCF}_{3}\right) ;{ }^{13} \mathrm{C}$ $\operatorname{NMR}\left(\mathrm{CDCl}_{3}\right): \delta 116.4,125.6,129.4\left(\mathrm{q}, J=313.6 \mathrm{~Hz}, \mathrm{SCF}_{3}\right), 135.0$, 157.2. IR (neat) $\mathrm{cm}^{-1}: 3330,1583,1493,1431,1244,1137,1088$, 825, 751. HRMS: (ESI-TOF) calcd for $\mathrm{C}_{7} \mathrm{H}_{4} \mathrm{~F}_{3} \mathrm{OS}_{2} 224.9664$, found $224.9664(\mathrm{M}-\mathrm{H})^{+}$.

1-Methoxy-2-((trifluoromethyl)sulfinothioyl)benzene (3d). (0.5 mmol of $2 \mathrm{~d}, 0.6 \mathrm{mmol}$ of $1,0.6 \mathrm{mmol}$ of MSA). Yellow oil (109 mg, 91\%). ${ }^{1} \mathrm{H}$ NMR $\left(\mathrm{CDCl}_{3}\right): \delta 3.91(\mathrm{~s}, 3 \mathrm{H}), 6.88-6.93(\mathrm{~m}$, $1 \mathrm{H}), 6.98(\mathrm{dt}, J=7.6,1.0 \mathrm{~Hz}, 1 \mathrm{H}), 7.31-7.37(\mathrm{~m}, 1 \mathrm{H}), 7.64(\mathrm{dd}, J=$ 7.7, $1.3 \mathrm{~Hz}, 1 \mathrm{H}) ;{ }^{19} \mathrm{~F}$ NMR $\left(\mathrm{CDCl}_{3}\right): \delta-46.1\left(\mathrm{~s}, \mathrm{SCF}_{3}\right) ;{ }^{13} \mathrm{C} \mathrm{NMR}$ $\left(\mathrm{CDCl}_{3}\right): \delta 56.0,111.2,121.2,122.2,129.3\left(\mathrm{q}, J=313.9 \mathrm{~Hz}, \mathrm{SCF}_{3}\right)$, 130.6, 131.6, 158.0; IR (neat) $\mathrm{cm}^{-1}$ : 2940, 2839, 1582, 1475, 1463, 1434, 1295, 1275, 1244, 1132, 1097, 1060, 1038, 1023, 798, 748, 678. HRMS: (CI + PI) calcd for $\mathrm{C}_{8} \mathrm{H}_{7} \mathrm{~F}_{3} \mathrm{OS}_{2} 239.9885$, found 239.9884.

2,4-Dimethyl-1-((trifluoromethyl)sulfinothioyl)benzene (3e). ( $0.5 \mathrm{mmol}$ of $2 \mathrm{e}, 0.6 \mathrm{mmol}$ of $1,0.6 \mathrm{mmol}$ of MSA). Yellow oil (107 mg, 90\%). ${ }^{1} \mathrm{H}$ NMR $\left(\mathrm{CDCl}_{3}\right): \delta 2.33(\mathrm{~s}, 3 \mathrm{H}), 2.46(\mathrm{~s}, 3 \mathrm{H})$, 7.00-7.04 (m, 1H), 7.05-7.08 (m, 1H), $7.55(\mathrm{~d}, J=7.9 \mathrm{~Hz}, 1 \mathrm{H}) ;{ }^{19} \mathrm{~F}$ NMR $\left(\mathrm{CDCl}_{3}\right): \delta-45.9\left(\mathrm{~s}, \mathrm{SCF}_{3}\right) ;{ }^{13} \mathrm{C} \mathrm{NMR}\left(\mathrm{CDCl}_{3}\right): \delta 20.4,21.1$, $127.8,129.4$ (q, $J=313.9 \mathrm{~Hz}, \mathrm{SCF}_{3}$ ), 130.0, 131.6, 133.4, 140.3, 140.3. IR (neat) $\mathrm{cm}^{-1}: 2923,1602,1475,1446,1378,1140,1096$, 1044, 875, 810, 751. HRMS: (CI) calcd for $\mathrm{C}_{9} \mathrm{H}_{9} \mathrm{~F}_{3} \mathrm{~S}_{2} 238.0092$, found 238.0092 .

1,4-Dimethyl-2-((trifluoromethyl)sulfinothioyl)benzene (3f). (0.5 mmol of $2 \mathrm{f}, 0.6 \mathrm{mmol}$ of $1,0.65 \mathrm{mmol}$ of MSA). Yellow oil (109 mg, 92\%). ${ }^{1} \mathrm{H}$ NMR $\left(\mathrm{CDCl}_{3}\right): \delta 2.33(\mathrm{~s}, 3 \mathrm{H}), 2.44(\mathrm{~s}, 3 \mathrm{H})$, 7.05-7.09 (m, 1H), 7.09-7.13 (m, 1H), 7.46-7.49 (m, 1H); ${ }^{19} \mathrm{~F}$ $\mathrm{NMR}\left(\mathrm{CDCl}_{3}\right): \delta-46.0\left(\mathrm{~s}, \mathrm{SCF}_{3}\right) ;{ }^{13} \mathrm{C} \mathrm{NMR}\left(\mathrm{CDCl}_{3}\right): \delta 19.8,20.8$, 129.3 (q, $J=314.0 \mathrm{~Hz}, \mathrm{SCF}_{3}$ ), 130.4, 130.6, 132.7, 132.9, 136.5, 136.8. IR (neat) $\mathrm{cm}^{-1}: 2923,1488,1447,1380,1097,874,811$, 751, 704. HRMS: (CI + PI) calcd for $\mathrm{C}_{9} \mathrm{H}_{9} \mathrm{~F}_{3} \mathrm{~S}_{2} 238.0092$, found 238.0094 .

1,3-Dimethyl-5-((trifluoromethyl)sulfinothioyl)benzene (3g). (0.5 mmol of $2 \mathrm{~g}, 0.6 \mathrm{mmol}$ of $\mathbf{1}, 0.65 \mathrm{mmol}$ of MSA). Yellow oil (106 mg, 89\%). ${ }^{1} \mathrm{H} \mathrm{NMR}\left(\mathrm{CDCl}_{3}\right): \delta 2.32(\mathrm{~s}, 6 \mathrm{H}), 6.96-6.99(\mathrm{~m}$, $1 \mathrm{H}), 7.18-7.21(\mathrm{~m}, 2 \mathrm{H}) ;{ }^{19} \mathrm{~F} \mathrm{NMR}\left(\mathrm{CDCl}_{3}\right): \delta-46.4\left(\mathrm{~s}, \mathrm{SCF}_{3}\right) ;{ }^{13} \mathrm{C}$ $\operatorname{NMR}\left(\mathrm{CDCl}_{3}\right): \delta 21.2,128.0,129.2\left(\mathrm{q}, J=314.0 \mathrm{~Hz}, \mathrm{SCF}_{3}\right), 130.9$,
134.1, 139.2. IR (neat) $\mathrm{cm}^{-1}: 2921,1602,1579,1142,1097,839$, 751, 681. HRMS: (CI + PI) calcd for $\mathrm{C}_{9} \mathrm{H}_{9} \mathrm{~F}_{3} \mathrm{~S}_{2} 238.0092$, found 238.0095 .

1-Isopropyl-4-((trifluoromethyl)sulfinothioyl)benzene $(3 \mathrm{~h})$. ( $0.5 \mathrm{mmol}$ of $2 \mathbf{h}, 0.6 \mathrm{mmol}$ of $\mathbf{1}, 0.70 \mathrm{mmol}$ of MSA). Yellow oil (113 mg, 90\%). ${ }^{1} \mathrm{H}$ NMR $\left(\mathrm{CDCl}_{3}\right): \delta 1.26(\mathrm{~d}, J=6.9 \mathrm{~Hz}, 6 \mathrm{H}), 2.93$ (sept, $J=6.9 \mathrm{~Hz}, 1 \mathrm{H}), 7.20-7.26(\mathrm{~m}, 2 \mathrm{H}), 7.49-7.56(\mathrm{~m}, 2 \mathrm{H}) ;{ }^{19} \mathrm{~F}$ NMR $\left(\mathrm{CDCl}_{3}\right): \delta-46.3\left(\mathrm{~s}, \mathrm{SCF}_{3}\right) ;{ }^{13} \mathrm{C} \mathrm{NMR}\left(\mathrm{CDCl}_{3}\right): \delta 23.8,33.9$, $127.6,129.3$ (q, $\left.J=313.9 \mathrm{~Hz}, \mathrm{SCF}_{3}\right), 131.4,131.4,150.6$. IR (neat) $\mathrm{cm}^{-1}:$ 2963, 1142, 1098, 1052, 824, 752. HRMS: (CI + PI) calcd for $\mathrm{C}_{10} \mathrm{H}_{11} \mathrm{~F}_{3} \mathrm{~S}_{2}$ 252.0249, found 252.0251.

2-((Trifluoromethyl)sulfinothioyl)naphthalene $(3 \mathrm{i}) .^{40} \quad(0.5$ mmol of $2 \mathbf{i}, 0.6 \mathrm{mmol}$ of $1,0.65 \mathrm{mmol}$ of MSA). Yellow oil (118 $\mathrm{mg}, 91 \%) .{ }^{1} \mathrm{H}$ NMR $\left(\mathrm{CDCl}_{3}\right): \delta 7.50-7.56(\mathrm{~m}, 2 \mathrm{H}), 7.64(\mathrm{dd}, J=$ 8.6, $1.9 \mathrm{~Hz}, 1 \mathrm{H}), 7.80-7.88(\mathrm{~m}, 3 \mathrm{H}), 8.08(\mathrm{~d}, J=1.9 \mathrm{~Hz}, 1 \mathrm{H}) ;{ }^{19} \mathrm{~F}$ $\mathrm{NMR}\left(\mathrm{CDCl}_{3}\right): \delta-46.2\left(\mathrm{~s}, \mathrm{SCF}_{3}\right) ;{ }^{13} \mathrm{C} \mathrm{NMR}\left(\mathrm{CDCl}_{3}\right): \delta$ 127.0, 127.2, 127.2, 127.8, 129.2 (q, $J=314.2 \mathrm{~Hz}, \mathrm{SCF}_{3}$ ), 129.4, 130.1, 131.6, 133.1, 133.3. IR (neat) $\mathrm{cm}^{-1}:$ 1140, 1094, 853, 808, 742 . HRMS: (APCI) calcd for $\mathrm{C}_{11} \mathrm{H}_{7} \mathrm{~F}_{3} \mathrm{~S}_{2} 259.9936$, found 259.9935 .

1-Chloro-4-((trifluoromethyl)sulfinothioyl)benzene $(3 \mathbf{j}))^{51}$ ( $0.5 \mathrm{mmol}$ of $2 \mathbf{j}, 0.6 \mathrm{mmol}$ of $\mathbf{1}, 0.65 \mathrm{mmol}$ of MSA). Yellow oil (103 mg, 84\%). ${ }^{1} \mathrm{H}$ NMR $\left(\mathrm{CDCl}_{3}\right): \delta 7.33-7.37(\mathrm{~m}, 2 \mathrm{H}), 7.51-7.55$ $(\mathrm{m}, 2 \mathrm{H}) ;{ }^{19} \mathrm{~F} \mathrm{NMR}\left(\mathrm{CDCl}_{3}\right): \delta-46.3\left(\mathrm{~s}, \mathrm{SCF}_{3}\right) ;{ }^{13} \mathrm{C} \mathrm{NMR}\left(\mathrm{CDCl}_{3}\right): \delta$ 129.0 (q, $\left.J=314.2 \mathrm{~Hz}, \mathrm{SCF}_{3}\right), 129.6,131.9,133.1,135.5$. IR (neat) $\mathrm{cm}^{-1}$ : 1475, 1389, 1143, 1092, 1012, 815, 752. HRMS: (APCI) calcd for $\mathrm{C}_{7} \mathrm{H}_{4} \mathrm{ClF}_{3} \mathrm{~S}_{2} 243.9389$, found 243.9380 .

((Trifluoromethyl)sulfinothioyl)benzene (3k). ${ }^{63}(0.5 \mathrm{mmol}$ of 2k, $0.6 \mathrm{mmol}$ of 1, $0.6 \mathrm{mmol}$ of $\mathrm{TfOH})$. Yellow oil (79 mg, 75\%). ${ }^{1} \mathrm{H}$ NMR $\left(\mathrm{CDCl}_{3}\right): \delta 7.34-7.40(\mathrm{~m}, 3 \mathrm{H}), 7.57-7.62(\mathrm{~m}, 2 \mathrm{H}) ;{ }^{19} \mathrm{~F}$ $\mathrm{NMR}\left(\mathrm{CDCl}_{3}\right): \delta-46.4\left(\mathrm{~s}, \mathrm{SCF}_{3}\right) ;{ }^{13} \mathrm{C} \mathrm{NMR}\left(\mathrm{CDCl}_{3}\right): \delta 129.0,129.1$ (q, $J=314.1 \mathrm{~Hz}, \mathrm{SCF}_{3}$ ), 129.4, 130.4, 134.6. IR (neat) $\mathrm{cm}^{-1}: 2923$, 2853, 1590, 1493, 1291, 1251, 1143, 1100, 1032, 751, 687. HRMS: (APCI) calcd for $\mathrm{C}_{7} \mathrm{H}_{5} \mathrm{~F}_{3} \mathrm{~S}_{2} 209.9779$, found 209.9779 .

1-Methoxy-3-((trifluoromethyl)sulfinothioyl)benzene (31). (0.5 mmol of $21,0.6 \mathrm{mmol}$ of $\mathbf{1}, 0.6 \mathrm{mmol}$ of $\mathrm{TfOH}$ ). Yellow oil (106 mg, 88\%). ${ }^{1} \mathrm{H}$ NMR $\left(\mathrm{CDCl}_{3}\right): \delta 3.82(\mathrm{~s}, 3 \mathrm{H}), 6.86-6.91(\mathrm{~m}$, $1 \mathrm{H}), 7.11-7.14(\mathrm{~m}, 1 \mathrm{H}), 7.14-7.18(\mathrm{~m}, 1 \mathrm{H}), 7.25-7.30(\mathrm{~m}, 1 \mathrm{H}) ;{ }^{19} \mathrm{~F}$ $\operatorname{NMR}\left(\mathrm{CDCl}_{3}\right): \delta-46.3\left(\mathrm{~s}, \mathrm{SCF}_{3}\right) ;{ }^{13} \mathrm{C} \mathrm{NMR}\left(\mathrm{CDCl}_{3}\right): \delta 55.4,114.9$, 115.0, 122.1, 129.0 (q, $\left.J=314.2 \mathrm{~Hz}, \mathrm{SCF}_{3}\right), 130.2,135.7,160.1$; IR (neat) $\mathrm{cm}^{-1}: 2837,1590,1576,1478,1425,1284,1249,1232$, 1140, 1096, 1039, 992, 858, 770, 752, 683. HRMS: (PI) calcd for $\mathrm{C}_{8} \mathrm{H}_{7} \mathrm{~F}_{3} \mathrm{OS}_{2} 239.9885$, found 239.9883 .

1-Fluoro-4-((trifluoromethyl)sulfinothioyl)benzene $(3 \mathrm{~m}){ }^{51}$ (0.5 mmol of $2 \mathrm{~m}, 0.55 \mathrm{mmol}$ of $1,0.6 \mathrm{mmol}$ of TfOH). Yellow oil (95 mg, 83\%). ${ }^{1} \mathrm{H}$ NMR $\left(\mathrm{CDCl}_{3}\right): \delta$ 7.04-7.11 (m, 2H), 7.57-7.63 $(\mathrm{m}, 2 \mathrm{H}) ;{ }^{19} \mathrm{~F} \mathrm{NMR}\left(\mathrm{CDCl}_{3}\right): \delta-46.3\left(\mathrm{~s}, \mathrm{SCF}_{3}\right),-111.1(\mathrm{~m}, 1 \mathrm{~F}) ;{ }^{13} \mathrm{C}$ NMR $\left(\mathrm{CDCl}_{3}\right): \delta 116.7(\mathrm{~d}, J=22.3 \mathrm{~Hz}), 129.2(\mathrm{q}, J=313.9 \mathrm{~Hz}$, $\left.\mathrm{SCF}_{3}\right), 130.0(\mathrm{~d}, J=3.3 \mathrm{~Hz}), 133.9$ (d, $\left.J=8.6 \mathrm{~Hz}\right), 163.5(\mathrm{~d}, J=$ $250.8 \mathrm{~Hz}$ ). IR (neat) $\mathrm{cm}^{-1}:$ 1589, 1489, 1234, 1142, 1096, 1013, 828, 752, 627. HRMS: (CI) calcd for $\mathrm{C}_{7} \mathrm{H}_{4} \mathrm{~F}_{4} \mathrm{~S}_{2} 227.9685$, found 227.9684 .

1-Fluoro-2-((trifluoromethyl)sulfinothioyl)benzene (3n). (0.5 mmol of $2 \mathrm{n}, 0.6 \mathrm{mmol}$ of $\mathbf{1}, 0.6 \mathrm{mmol}$ of $\mathrm{TfOH}$ ). Yellow oil (95 $\mathrm{mg}, 83 \%) .{ }^{1} \mathrm{H}$ NMR $\left(\mathrm{CDCl}_{3}\right): \delta 7.10-7.15(\mathrm{~m}, 1 \mathrm{H}), 7.16-7.21(\mathrm{~m}$, 1H), 7.35-7.43 (m, 1H), 7.63-7.69 (m, 1H); ${ }^{19} \mathrm{~F} \mathrm{NMR}\left(\mathrm{CDCl}_{3}\right): \delta$ $-46.3\left(\mathrm{~d}, J=2.4 \mathrm{~Hz}, \mathrm{SCF}_{3}\right),-108.3(\mathrm{~m}, 1 \mathrm{~F}) ;{ }^{13} \mathrm{C} \mathrm{NMR}\left(\mathrm{CDCl}_{3}\right): \delta$ $116.3(\mathrm{~d}, J=21.9 \mathrm{~Hz}), 121.7(\mathrm{~d}, J=17.3 \mathrm{~Hz}), 124.9(\mathrm{~d}, J=3.9 \mathrm{~Hz})$, 
129.1 (q, $\left.J=314.0 \mathrm{~Hz}, \mathrm{SCF}_{3}\right), 131.8$ (d, $\left.J=8.0 \mathrm{~Hz}\right), 133.7,161.5$ $(\mathrm{d}, J=249.6 \mathrm{~Hz})$. IR (neat) $\mathrm{cm}^{-1}: 1472,1448,1263,1229,1143$, 1096, 826, 752. HRMS: (CI + PI) calcd for $\mathrm{C}_{7} \mathrm{H}_{4} \mathrm{~F}_{4} \mathrm{~S}_{2} 227.9685$, found 227.9685 .

2,4-Difluoro-1-((trifluoromethyl)sulfinothioyl)benzene (3o). (0.5 mmol of $20,0.6 \mathrm{mmol}$ of $\mathbf{1}, 0.6 \mathrm{mmol}$ of $\mathrm{TfOH}$ ). Yellow oil (99 mg, 80\%). ${ }^{1} \mathrm{H} \mathrm{NMR}\left(\mathrm{CDCl}_{3}\right): \delta 6.87-6.97(\mathrm{~m}, 2 \mathrm{H}), 7.62-7.69$ $(\mathrm{m}, 1 \mathrm{H}) ;{ }^{19} \mathrm{~F} \mathrm{NMR}\left(\mathrm{CDCl}_{3}\right): \delta-46.3\left(\mathrm{~d}, J=3.0 \mathrm{~Hz}, \mathrm{SCF}_{3}\right),-102.0$ $(\mathrm{m}, 1 \mathrm{~F}),-105.1(\mathrm{~m}, 1 \mathrm{~F}) ;{ }^{13} \mathrm{C} \mathrm{NMR}\left(\mathrm{CDCl}_{3}\right): \delta 105.1(\mathrm{t}, J=26.0$ $\mathrm{Hz}), 112.5$ (dd, $J=21.9,3.9 \mathrm{~Hz}), 117.5(\mathrm{dd}, J=18.1,4.1 \mathrm{~Hz}$ ), 129.1 (q, $\left.J=313.8 \mathrm{~Hz}, \mathrm{SCF}_{3}\right), 136.2(\mathrm{~d}, J=10.0 \mathrm{~Hz}), 162.5(\mathrm{dd}, J=$ 252.9, $12.7 \mathrm{~Hz}$ ), 164.5 (dd, $J=254.3,11.3 \mathrm{~Hz}$ ); IR (neat) $\mathrm{cm}^{-1}$ : 2926, 2854, 1596, 1484, 1466, 1421, 1268, 1143, 1099, 966, 852, 810, 752. HRMS: (PI) calcd for $\mathrm{C}_{7} \mathrm{H}_{3} \mathrm{~F}_{5} \mathrm{~S}_{2}$ 245.9591, found 245.9589 .

1,2-Dichloro-4-((trifluoromethyl)sulfinothioyl)benzene (3p). (0.5 mmol of $2 \mathrm{p}, 0.6 \mathrm{mmol}$ of $1,0.6 \mathrm{mmol}$ of $\mathrm{TfOH}$ ). Yellow oil $(123 \mathrm{mg}, 88 \%) .{ }^{1} \mathrm{H}$ NMR $\left(\mathrm{CDCl}_{3}\right): \delta 7.41(\mathrm{dd}, J=8.4,2.1 \mathrm{~Hz}, 1 \mathrm{H})$, $7.45(\mathrm{~d}, J=8.4 \mathrm{~Hz}, 1 \mathrm{H}), 7.67$ (d, $J=2.1 \mathrm{~Hz}, 1 \mathrm{H}) ;{ }^{19} \mathrm{~F}$ NMR $\left(\mathrm{CDCl}_{3}\right): \delta-46.2\left(\mathrm{~s}, \mathrm{SCF}_{3}\right) ;{ }^{13} \mathrm{C} \mathrm{NMR}\left(\mathrm{CDCl}_{3}\right): \delta 128.8(\mathrm{q}, J=314.5$ $\left.\mathrm{Hz}, \mathrm{SCF}_{3}\right), 129.1,131.1,131.5,133.5,133.6,134.5$. IR (neat) $\mathrm{cm}^{-1}:$ 1458, 1367, 1143, 1095, 1031, 808, 752. HRMS: (APCI + PI) calcd for $\mathrm{C}_{7} \mathrm{H}_{3} \mathrm{Cl}_{2} \mathrm{~F}_{3} \mathrm{~S}_{2} 277.9000$, found 277.8999 .

1,4-Dichloro-2-((trifluoromethyl)sulfinothioyl)benzene (3q). (0.5 mmol of 2q, $0.6 \mathrm{mmol}$ of 1, $0.6 \mathrm{mmol}$ of $\mathrm{TfOH}$ ). Yellow oil (125 mg, 89\%). ${ }^{1} \mathrm{H} \mathrm{NMR}\left(\mathrm{CDCl}_{3}\right): \delta 7.24(\mathrm{dd}, J=8.5,2.4 \mathrm{~Hz}, 1 \mathrm{H})$, $7.33(\mathrm{~d}, J=8.5 \mathrm{~Hz}, 1 \mathrm{H}), 7.71$ (d, $J=2.4 \mathrm{~Hz}, 1 \mathrm{H}) ;{ }^{19} \mathrm{~F}$ NMR $\left(\mathrm{CDCl}_{3}\right): \delta-45.9\left(\mathrm{~s}, \mathrm{SCF}_{3}\right) ;{ }^{13} \mathrm{C} \mathrm{NMR}\left(\mathrm{CDCl}_{3}\right): \delta 128.6(\mathrm{q}, J=314.8$ $\left.\mathrm{Hz}, \mathrm{SCF}_{3}\right), 129.0,129.5,131.0,131.5,133.7,134.9 . \mathrm{IR}$ (neat) $\mathrm{cm}^{-1}$ : 1447, 1149, 1091, 1030, 868, 810, 752. HRMS: (CI) calcd for $\mathrm{C}_{7} \mathrm{H}_{3} \mathrm{Cl}_{2} \mathrm{~F}_{3} \mathrm{~S}_{2} 277.9000$, found 277.9003 .

1-(Trifluoromethyl)-3-((trifluoromethyl)sulfinothioyl)benzene (3r). (0.5 mmol of $2 r, 0.6 \mathrm{mmol}$ of $1,0.6 \mathrm{mmol}$ of TfOH). Yellow oil (114 mg, 82\%). ${ }^{1} \mathrm{H}$ NMR $\left(\mathrm{CDCl}_{3}\right): \delta 7.49-7.55(\mathrm{~m}, 1 \mathrm{H}), 7.58-$ $7.63(\mathrm{~m}, 1 \mathrm{H}), 7.75-7.80(\mathrm{~m}, 1 \mathrm{H}), 7.82-7.86(\mathrm{~m}, 1 \mathrm{H}) ;{ }^{19} \mathrm{~F}$ NMR $\left(\mathrm{CDCl}_{3}\right): \delta-46.3\left(\mathrm{~s}, \mathrm{SCF}_{3}\right),-63.4\left(\mathrm{~s}, \mathrm{CF}_{3}\right) ;{ }^{13} \mathrm{C} \mathrm{NMR}\left(\mathrm{CDCl}_{3}\right): \delta$ $123.4\left(\mathrm{q}, J=272.7 \mathrm{~Hz}, \mathrm{CF}_{3}\right), 125.6$ (q, $\left.J=3.6 \mathrm{~Hz}\right), 126.3$ (q, $J=3.6$ $\mathrm{Hz}), 128.8$ (q, $\left.J=314.4 \mathrm{~Hz}, \mathrm{SCF}_{3}\right), 129.9,131.9$ (q, $J=32.9 \mathrm{~Hz}$, $\mathrm{SCF}_{3}$ ), 132.7, 136.1. IR (neat) $\mathrm{cm}^{-1}:$ 1321, 1284, 1129, 1096, 1071, 794, 752, 694, 683, 651. HRMS: (CI + PI) calcd for $\mathrm{C}_{8} \mathrm{H}_{4} \mathrm{~F}_{6} \mathrm{~S}_{2}$ 277.9653 , found 277.9655 .

1-Nitro-4-((trifluoromethyl)sulfinothioyl)benzene $(3 \mathrm{~s}) .^{51}(0.5$ mmol of $2 \mathrm{~s}, 0.6 \mathrm{mmol}$ of $1,0.6 \mathrm{mmol}$ of $\mathrm{TfOH})$. Yellow oil (111 $\mathrm{mg}, 87 \%) .{ }^{1} \mathrm{H}$ NMR $\left(\mathrm{CDCl}_{3}\right): \delta 7.69-7.75(\mathrm{~m}, 2 \mathrm{H}), 8.22-8.27(\mathrm{~m}$, $2 \mathrm{H}) ;{ }^{19} \mathrm{~F} \mathrm{NMR}\left(\mathrm{CDCl}_{3}\right): \delta-46.1\left(\mathrm{~s}, \mathrm{SCF}_{3}\right) ;{ }^{13} \mathrm{C} \mathrm{NMR}\left(\mathrm{CDCl}_{3}\right): \delta$ 124.4, 127.8, 128.5 (q, $\left.J=315.0 \mathrm{~Hz}, \mathrm{SCF}_{3}\right), 142.9$, 147.4. IR (neat) $\mathrm{cm}^{-1}: 1578,1518,1339,1145,1092,843,740,680$. HRMS: (ESI-TOF) calcd for $\mathrm{C}_{7} \mathrm{H}_{5} \mathrm{~F}_{3} \mathrm{NO}_{2} \mathrm{~S}_{2}$ 255.9708, found $255.9715(\mathrm{M}+\mathrm{H})^{+}$.

1-Methoxy-4-(((trifluoromethyl)sulfinothioyl)methyl)benzene (5a). (0.5 mmol of $4 a, 0.6 \mathrm{mmol}$ of $1,0.6 \mathrm{mmol}$ of MSA). Yellow oil (120 mg, 94\%). ${ }^{1} \mathrm{H}$ NMR $\left(\mathrm{CDCl}_{3}\right): \delta 3.81$ (s, 3H), $4.05(\mathrm{~s}, 2 \mathrm{H})$, 6.84-6.91 (m, 2H), 7.20-7.27 (m, 2H); ${ }^{19} \mathrm{~F} \mathrm{NMR}\left(\mathrm{CDCl}_{3}\right): \delta-46.4$ $\left(\mathrm{s}, \mathrm{SCF}_{3}\right) ;{ }^{13} \mathrm{C} \mathrm{NMR}\left(\mathrm{CDCl}_{3}\right): \delta 43.9,55.3,114.2,127.1,129.7$ (q, $J$ $=313.6 \mathrm{~Hz}, \mathrm{SCF}_{3}$ ), 130.7, 159.5; IR (neat) $\mathrm{cm}^{-1}$ : 1609, 1510, 1302, 1250, 1235, 1135, 1096, 1033, 830, 749. HRMS: (CI + PI) calcd for $\mathrm{C}_{9} \mathrm{H}_{8} \mathrm{~F}_{3} \mathrm{OS}_{2} 252.9963$, found $252.9963(\mathrm{M}-\mathrm{H})^{+}$.
(((Trifluoromethyl)sulfinothioyl)methyl)benzene $(5 \mathrm{~b}){ }^{40}(0.5$ $\mathrm{mmol}$ of $4 \mathbf{b}, 0.6 \mathrm{mmol}$ of $1,0.6 \mathrm{mmol}$ of MSA). Yellow oil (90 mg, $80 \%) .{ }^{1} \mathrm{H} \mathrm{NMR}\left(\mathrm{CDCl}_{3}\right): \delta 4.09(\mathrm{~s}, 2 \mathrm{H}), 7.28-7.39(\mathrm{~m}, 5 \mathrm{H}) ;{ }^{19} \mathrm{~F}$ $\mathrm{NMR}\left(\mathrm{CDCl}_{3}\right): \delta-46.4\left(\mathrm{~s}, \mathrm{SCF}_{3}\right) ;{ }^{13} \mathrm{C} \mathrm{NMR}\left(\mathrm{CDCl}_{3}\right): \delta 44.4,128.1$, 128.8, 129.5, 129.6 (q, $J=313.7 \mathrm{~Hz}, \mathrm{SCF}_{3}$ ), 135.3. IR (neat) $\mathrm{cm}^{-1}$ : 1135, 1097, 751, 696. HRMS: (APCI + PI) calcd for $\mathrm{C}_{8} \mathrm{H}_{6} \mathrm{~F}_{3} \mathrm{~S}_{2}$ 222.9857, found 222.9858 $(\mathrm{M}-\mathrm{H})^{+}$.

1-Fluoro-4-(((trifluoromethyl)sulfinothioyl)methyl)benzene (5c). ( $0.5 \mathrm{mmol}$ of $4 \mathrm{c}, 0.6 \mathrm{mmol}$ of $1,0.65 \mathrm{mmol}$ of MSA). Yellow oil (95 mg, 78\%). ${ }^{1} \mathrm{H} \mathrm{NMR}\left(\mathrm{CDCl}_{3}\right): \delta 4.05(\mathrm{~s}, 2 \mathrm{H}), 7.01-7.07(\mathrm{~m}, 2 \mathrm{H})$, 7.24-7.30 (m, 2H); ${ }^{19} \mathrm{~F} \mathrm{NMR}\left(\mathrm{CDCl}_{3}\right): \delta-46.3\left(\mathrm{~s}, \mathrm{SCF}_{3}\right),-114.1$ $(\mathrm{m}, 1 \mathrm{~F}) ;{ }^{13} \mathrm{C} \mathrm{NMR}\left(\mathrm{CDCl}_{3}\right): \delta 43.4,115.7(\mathrm{~d}, J=21.7 \mathrm{~Hz}), 129.5(\mathrm{q}$, $\left.J=313.7 \mathrm{~Hz}, \mathrm{SCF}_{3}\right), 131.1(\mathrm{~d}, J=3.2 \mathrm{~Hz}), 131.2(\mathrm{~d}, J=8.3 \mathrm{~Hz})$, 162.5 (d, $J=247.3 \mathrm{~Hz}$ ). IR (neat) $\mathrm{cm}^{-1}: 1509,1227,1137,1098$, 834. HRMS: (CI + PI) calcd for $\mathrm{C}_{8} \mathrm{H}_{6} \mathrm{~F}_{4} \mathrm{~S}_{2}$ 241.9841, found 241.9843.

1-Chloro-4-(((trifluoromethyl)sulfinothioyl)methyl)benzene (5d). ( $0.5 \mathrm{mmol}$ of $4 \mathrm{~d}, 0.6 \mathrm{mmol}$ of $\mathbf{1}, 0.65 \mathrm{mmol}$ of MSA). Yellow oil (113 mg, 87\%). ${ }^{1} \mathrm{H}$ NMR $\left(\mathrm{CDCl}_{3}\right): \delta 4.03(\mathrm{~s}, 2 \mathrm{H}), 7.22-7.27(\mathrm{~m}$, 2H), 7.31-7.35 (m, 2H); ${ }^{19} \mathrm{~F} \mathrm{NMR}\left(\mathrm{CDCl}_{3}\right): \delta-46.3\left(\mathrm{~s}, \mathrm{SCF}_{3}\right) ;{ }^{13} \mathrm{C}$ NMR $\left(\mathrm{CDCl}_{3}\right): \delta 43.5,129.0,129.5$ (q, $\left.J=313.8 \mathrm{~Hz}, \mathrm{SCF}_{3}\right), 130.8$, 133.8, 134.1. IR (neat) $\mathrm{cm}^{-1}$ : 1490, 1136, 1093, 1015, 831. HRMS: $(\mathrm{APCI}+\mathrm{PI})$ calcd for $\mathrm{C}_{8} \mathrm{H}_{5} \mathrm{ClF}_{3} \mathrm{~S}_{2}$ 256.9468, found 256.9468 $(\mathrm{M}-\mathrm{H})^{+}$.

1-(Trifluoromethyl)-3-(((trifluoromethyl)sulfinothioyl)methyl)benzene (5e). ( $0.5 \mathrm{mmol}$ of $4 \mathrm{e}, 0.6 \mathrm{mmol}$ of $1,0.6 \mathrm{mmol}$ of MSA). Yellow oil (136 mg, 93\%). ${ }^{1} \mathrm{H} \mathrm{NMR}\left(\mathrm{CDCl}_{3}\right): \delta 4.10(\mathrm{~s}, 2 \mathrm{H}), 7.47-$ $7.52(\mathrm{~m}, 2 \mathrm{H}), 7.55-7.60(\mathrm{~m}, 2 \mathrm{H}) ;{ }^{19} \mathrm{~F} \mathrm{NMR}\left(\mathrm{CDCl}_{3}\right): \delta-46.2(\mathrm{~s}$, $\left.\mathrm{SCF}_{3}\right),-63.3\left(\mathrm{~s}, \mathrm{CF}_{3}\right) ;{ }^{13} \mathrm{C} \mathrm{NMR}\left(\mathrm{CDCl}_{3}\right): \delta 43.5,123.8(\mathrm{q}, J=$ $272.3 \mathrm{~Hz}), 124.9$ (q, $J=3.5 \mathrm{~Hz}), 126.2(\mathrm{q}, J=3.7 \mathrm{~Hz}), 129.3,129.4$ (q, $\left.J=313.9 \mathrm{~Hz}, \mathrm{SCF}_{3}\right), 131.2(\mathrm{q}, J=32.5 \mathrm{~Hz}), 132.8$, 136.4. IR (neat) $\mathrm{cm}^{-1}: 1329,1124,1099,1075,906,888,803,750,700,659$. HRMS: (PI) calcd for $\mathrm{C}_{9} \mathrm{H}_{5} \mathrm{~F}_{6} \mathrm{~S}_{2} 290.9731$, found $290.9724(\mathrm{M}-$ $\mathrm{H})^{+}$.

1-(((Trifluoromethyl)sulfinothioyl)ethyl)benzene (5f). (1 mmol of $4 \mathbf{f}, 1.2 \mathrm{mmol}$ of $1,1.3 \mathrm{mmol}$ of MSA). Slightly yellow oil (138 $\mathrm{mg}, 58 \%) .{ }^{1} \mathrm{H}$ NMR $\left(\mathrm{CDCl}_{3}\right): \delta 1.73(\mathrm{~d}, J=7.0 \mathrm{~Hz}, 3 \mathrm{H}), 4.25(\mathrm{q}, J=$ $7.0 \mathrm{~Hz}, 1 \mathrm{H}), 7.28-7.38(\mathrm{~m}, 5 \mathrm{H}) ;{ }^{19} \mathrm{~F} \mathrm{NMR}\left(\mathrm{CDCl}_{3}\right): \delta-46.2\left(\mathrm{~s}, \mathrm{SCF}_{3}\right)$; ${ }^{13} \mathrm{C} \mathrm{NMR}\left(\mathrm{CDCl}_{3}\right): \delta 20.4,50.9,127.8,128.2,128.7,129.4(\mathrm{q}, J=$ $313.7 \mathrm{~Hz}, \mathrm{SCF}_{3}$ ) 140.1. IR (neat) $\mathrm{cm}^{-1}:$ 3032, 2973, 2929, 1493, 1454, 1376, 1135, 1099, 764, 751, 696. HRMS: (PI) calcd for $\mathrm{C}_{9} \mathrm{H}_{8} \mathrm{~F}_{3} \mathrm{~S}_{2}$ 237.0014, found: $237.0005(\mathrm{M}-\mathrm{H})^{+}$.

1-((Trifluoromethyl)sulfinothioyl)octane $(5 \mathrm{~g})$. ( $0.5 \mathrm{mmol}$ of $4 \mathrm{~g}, 0.6 \mathrm{mmol}$ of $1,0.65 \mathrm{mmol}$ of MSA). Yellow oil (102 mg, 83\%). ${ }^{1} \mathrm{H}$ NMR $\left(\mathrm{CDCl}_{3}\right): \delta 0.89(\mathrm{t}, J=7.1 \mathrm{~Hz}, 3 \mathrm{H}), 1.21-1.35(\mathrm{~m}, 8 \mathrm{H})$, 1.35-1.44 (m, 2H), 1.66-1.74 (m, 2H), 2.83-2.89 (m, 2H); ${ }^{19} \mathrm{~F}$ $\mathrm{NMR}\left(\mathrm{CDCl}_{3}\right): \delta-46.7\left(\mathrm{~s}, \mathrm{SCF}_{3}\right) ;{ }^{13} \mathrm{C} \mathrm{NMR}\left(\mathrm{CDCl}_{3}\right): \delta$ 14.1, 22.6, 28.2 28.6, 29.0, 29.1, 31.8, 39.9, 129.6 (q, $J=313.4 \mathrm{~Hz}, \mathrm{SCF}_{3}$ ); IR (neat) $\mathrm{cm}^{-1}$ : 2958, 2926, 2856, 1140, 1101, 751. HRMS: (PI) calcd for $\mathrm{C}_{9} \mathrm{H}_{17} \mathrm{~F}_{3} \mathrm{~S}_{2} 246.0718$, found 246.0714.

1-((Trifluoromethyl)sulfinothioyl)dodecane $(5 \mathrm{~h}) \cdot(0.5 \mathrm{mmol}$ of $4 \mathrm{~h}, 0.6 \mathrm{mmol}$ of $1,0.65 \mathrm{mmol}$ of MSA). Yellow oil $(130 \mathrm{mg}$, $86 \%) .{ }^{1} \mathrm{H} \mathrm{NMR}\left(\mathrm{CDCl}_{3}\right): \delta 0.87(\mathrm{t}, J=6.9 \mathrm{~Hz}, 3 \mathrm{H}), 1.20-1.44(\mathrm{~m}$, $18 \mathrm{H}), 1.63-1.76(\mathrm{~m}, 2 \mathrm{H}), 2.86(\mathrm{t}, J=7.4 \mathrm{~Hz}, 2 \mathrm{H}) ;{ }^{19} \mathrm{~F}$ NMR $\left(\mathrm{CDCl}_{3}\right): \delta-46.7\left(\mathrm{~s}, \mathrm{SCF}_{3}\right) ;{ }^{13} \mathrm{C} \mathrm{NMR}\left(\mathrm{CDCl}_{3}\right): \delta 14.1,22.7,28.3$, 28.6, 29.1, 29.3, 29.4, 29.5, 29.6, 31.9, 40.0, 129.6 (q, $J=313.5$ 
$\mathrm{Hz}, \mathrm{SCF}_{3}$ ). IR (neat) $\mathrm{cm}^{-1}: 2924,2854,1140,1102,751 . \mathrm{HRMS}$ : $\left(\right.$ APCI + PI) calcd for $\mathrm{C}_{13} \mathrm{H}_{25} \mathrm{~F}_{3} \mathrm{~S}_{2} 302.1344$, found 302.1341.

((Trifluoromethyl)sulfinothioyl)cyclohexane (5i). (1 mmol of 4i, $1.2 \mathrm{mmol}$ of 1, $2 \mathrm{mmol}$ of MSA). Slightly yellow oil (123 mg, 57\%). ${ }^{1} \mathrm{H}$ NMR $\left(\mathrm{CDCl}_{3}\right): \delta 1.18-1.43(\mathrm{~m}, 5 \mathrm{H}), 1.60-1.68(\mathrm{~m}, 1 \mathrm{H})$, 1.75-1.87 (m, 2H), 2.02-2.13 (m, 2H), 2.86-2.98 (m, $1 \mathrm{H}) ;{ }^{19} \mathrm{~F}$ $\mathrm{NMR}\left(\mathrm{CDCl}_{3}\right): \delta-46.6\left(\mathrm{~s}, \mathrm{SCF}_{3}\right) ;{ }^{13} \mathrm{C} \mathrm{NMR}\left(\mathrm{CDCl}_{3}\right): \delta 25.4,25.8$, $32.3,50.1,129.3$ (q, $J=313.4 \mathrm{~Hz}, \mathrm{SCF}_{3}$ ); IR (neat) $\mathrm{cm}^{-1}: 2933$, 2856, 1449, 1137, 1099, 996, 751. HRMS: (PI) calcd for $\mathrm{C}_{7} \mathrm{H}_{11} \mathrm{~F}_{3} \mathrm{~S}_{2}$ 216.0249 , found 216.0248 .

1,6-Bis((trifluoromethyl)sulfinothioyl)hexane (5j). (0.5 mmol of $4 \mathbf{j}, 1.2 \mathrm{mmol}$ of $\mathbf{1}, 1.3 \mathrm{mmol}$ of MSA). Yellow oil (154 mg, 88\%). ${ }^{1} \mathrm{H}$ NMR $\left(\mathrm{CDCl}_{3}\right): \delta 1.40-1.47(\mathrm{~m}, 4 \mathrm{H}), 1.68-1.77(\mathrm{~m}, 4 \mathrm{H})$, $2.87(\mathrm{t}, J=7.3 \mathrm{~Hz}, 4 \mathrm{H}) ;{ }^{19} \mathrm{~F} \mathrm{NMR}\left(\mathrm{CDCl}_{3}\right): \delta-46.6\left(\mathrm{~s}, \mathrm{SCF}_{3}\right) ;{ }^{13} \mathrm{C}$ NMR $\left(\mathrm{CDCl}_{3}\right): \delta 27.7,28.4,39.7,129.5\left(\mathrm{q}, J=313.5 \mathrm{~Hz}, \mathrm{SCF}_{3}\right)$. IR (neat) $\mathrm{cm}^{-1}: 2932,1135,1097,750$. HRMS: (APCI + PI) calcd for $\mathrm{C}_{8} \mathrm{H}_{12} \mathrm{~F}_{6} \mathrm{~S}_{4} 349.9720$, found 349.9719 .

1,3,5-Trimethyl-2-((trifluoromethyl)sulfinothioyl)benzene (7a). (0.5 mmol of $6 \mathrm{a}, 0.6 \mathrm{mmol}$ of $1,0.6 \mathrm{mmol}$ of $\mathrm{TfOH}$ ). Yellow oil (118 mg, 93\%). ${ }^{1} \mathrm{H} \mathrm{NMR}\left(\mathrm{CDCl}_{3}\right): \delta 2.29(\mathrm{~s}, 3 \mathrm{H}), 2.52(\mathrm{~s}, 6 \mathrm{H}), 6.96$ $(\mathrm{s}, 2 \mathrm{H}) ;{ }^{19} \mathrm{~F} \mathrm{NMR}\left(\mathrm{CDCl}_{3}\right): \delta-45.4\left(\mathrm{~s}, \mathrm{SCF}_{3}\right) ;{ }^{13} \mathrm{C} \mathrm{NMR}\left(\mathrm{CDCl}_{3}\right): \delta$ 21.1, 21.4, 129.2, 129.6, 129.6 (q, $J=313.6 \mathrm{~Hz}, \mathrm{SCF}_{3}$ ), 140.6, 142.8. IR (neat) $\mathrm{cm}^{-1}: 2925,1601,1459,1377,1138,1096,850$, 752. HRMS: (PI) calcd for $\mathrm{C}_{10} \mathrm{H}_{11} \mathrm{~F}_{3} \mathrm{~S}_{2} 252.0249$, found 252.0248.

(((Trifluoromethyl)sulfinothioyl)methanetriyl)tribenzene (7b). (0.5 mmol of $\mathbf{6 b}, 0.6 \mathrm{mmol}$ of $\mathbf{1}, 0.6 \mathrm{mmol}$ of $\mathrm{TfOH})$. White crystals (168 mg, 89\%), mp 72.5-73.4 ${ }^{\circ} \mathrm{C} .{ }^{1} \mathrm{H}$ NMR $\left(\mathrm{CDCl}_{3}\right): \delta$ 7.25-7.39 (m, 15H); ${ }^{19} \mathrm{~F} \mathrm{NMR}\left(\mathrm{CDCl}_{3}\right): \delta-43.6\left(\mathrm{~s}, \mathrm{SCF}_{3}\right) ;{ }^{13} \mathrm{C}$ $\mathrm{NMR}\left(\mathrm{CDCl}_{3}\right): \delta 73.3,127.5,128.0,128.3\left(\mathrm{q}, J=315.9 \mathrm{~Hz}, \mathrm{SCF}_{3}\right)$, 130.1, 142.6. IR (neat) $\mathrm{cm}^{-1}: 1488,1439,1137,1093,1032,1000$, 757, 726, 698, 664, 625, 616. Anal. calcd for $\mathrm{C}_{20} \mathrm{H}_{15} \mathrm{~F}_{3} \mathrm{~S}_{2}$ : C, 63.81; H, 4.02. Found: C, 63.64; H, 3.73.

2-((Trifluoromethyl)sulfinothioyl)-1,1'-biphenyl (7c). (0.8 mmol of $6 \mathbf{c}, 0.96 .0 \mathrm{mmol}$ of $1,4.0 \mathrm{mmol}$ of $p$-toluenesulfonic acid hydrate). Yellow oil (167 mg, 73\%). ${ }^{1} \mathrm{H}$ NMR $\left(\mathrm{CDCl}_{3}\right): \delta 7.29$ (dd, $J$ $=7.5,1.6 \mathrm{~Hz}, 1 \mathrm{H}), 7.34-7.47(\mathrm{~m}, 7 \mathrm{H}), 7.83(\mathrm{dd}, J=7.8,1.1 \mathrm{~Hz}, 1 \mathrm{H})$; ${ }^{19} \mathrm{~F} \mathrm{NMR}\left(\mathrm{CDCl}_{3}\right): \delta-46.0\left(\mathrm{~s}, \mathrm{SCF}_{3}\right) ;{ }^{13} \mathrm{C} \mathrm{NMR}\left(\mathrm{CDCl}_{3}\right): \delta 128.0$, 128.2, 128.3, 128.4, 129.0 (q, $J=314.5 \mathrm{~Hz}, \mathrm{SCF}_{3}$ ), 129.2 (q, $J=1.0$ $\mathrm{Hz}), 129.5$, 130.6, 132.9, 139.3, 142.7. IR (neat) $\mathrm{cm}^{-1}: 1586,1142$, $1100,748,700$. Anal. calcd for $\mathrm{C}_{13} \mathrm{H}_{9} \mathrm{~F}_{3} \mathrm{~S}_{2}$ : C 54.53; H 3.17. Found: C 54.38; H 2.89 .

4-Methyl-1,2-bis((trifluoromethyl)sulfinothioyl)benzene (7d). ( $1 \mathrm{mmol}$ of $\mathbf{6 d}, 2.4 \mathrm{mmol}$ of $1,2.6 \mathrm{mmol}$ of TfOH). Slightly yellow oil (185 mg, 52\%). ${ }^{1} \mathrm{H}$ NMR $\left(\mathrm{CDCl}_{3}\right): \delta 2.41(\mathrm{~s}, 3 \mathrm{H}), 7.18(\mathrm{dd}, J=$ 8.0, 1.1 Hz, 1H), $7.57(\mathrm{~d}, J=1.1 \mathrm{~Hz}, 1 \mathrm{H}), 7.62(\mathrm{~d}, J=8.0 \mathrm{~Hz}, 1 \mathrm{H})$; ${ }^{19} \mathrm{~F} \mathrm{NMR}\left(\mathrm{CDCl}_{3}\right): \delta-45.6\left(\mathrm{~s}, \mathrm{SCF}_{3}\right),-45.7\left(\mathrm{~s}, \mathrm{SCF}_{3}\right) ;{ }^{13} \mathrm{C} \mathrm{NMR}$ $\left(\mathrm{CDCl}_{3}\right): \delta 21.2,128.9\left(\mathrm{q}, J=314.5 \mathrm{~Hz}, \mathrm{SCF}_{3}\right), 129.2(\mathrm{q}, J=314.2$ $\mathrm{Hz}, \mathrm{SCF}_{3}$ ), 130.6, 131.2, 131.7, 132.9, 136.6, 141.3. IR (neat) $\mathrm{cm}^{-1}$ : 2049, 1587, 1457, 1140, 1087, 1030, 813, 751. HRMS (CI + PI): calcd for $\mathrm{C}_{9} \mathrm{H}_{6} \mathrm{~F}_{6} \mathrm{~S}_{4}$ : 355.9251, found: 355.9248 .

2-((Trifluoromethyl)sulfinothioyl)thiophene (7e). (1 mmol of 6e. $1.2 \mathrm{mmol}$ of 1, $2 \mathrm{mmol}$ of MSA). Yellow oil (115 mg, $53 \%) .{ }^{1} \mathrm{H}$ NMR $\left(\mathrm{CDCl}_{3}\right): \delta 7.03(\mathrm{dd}, J=5.3,3.7 \mathrm{~Hz}, 1 \mathrm{H}), 7.42(\mathrm{dd}, J=3.7$, $1.1 \mathrm{~Hz}, 1 \mathrm{H}), 7.53(\mathrm{dd}, J=5.3,1.1 \mathrm{~Hz}, 1 \mathrm{H}) ;{ }^{19} \mathrm{~F} \mathrm{NMR}\left(\mathrm{CDCl}_{3}\right): \delta$ $-45.9\left(\mathrm{~s}, \mathrm{SCF}_{3}\right) ;{ }^{13} \mathrm{C} \mathrm{NMR}\left(\mathrm{CDCl}_{3}\right): \delta 127.9,129.3(\mathrm{q}, J=313.2 \mathrm{~Hz}$, $\left.\mathrm{SCF}_{3}\right), 132.6,133.3,137.4$. IR (neat) $\mathrm{cm}^{-1}: 1140,1096,991,851$,
837, 752, 705. HRMS: (CI + PI) calcd for $\mathrm{C}_{5} \mathrm{H}_{3} \mathrm{~F}_{3} \mathrm{~S}_{3}$ 215.9343, found 215.9343 .

2-((Trifluoromethyl)sulfinothioyl)pyrimidine (7f). (1.0 $\mathrm{mmol}$ of $6 \mathbf{f}, 1.2 \mathrm{mmol}$ of $1,5.0 \mathrm{mmol}$ of $p$-toluenesulfonic acid hydrate). Bright brown solid (127 mg, 60\%), $\mathrm{mp}=42-45{ }^{\circ} \mathrm{C} .{ }^{1} \mathrm{H}$ $\operatorname{NMR}\left(\mathrm{CDCl}_{3}\right): \delta 7.20(\mathrm{t}, J=4.8 \mathrm{~Hz}, 1 \mathrm{H}), 8.68(\mathrm{~d}, J=4.8 \mathrm{~Hz}, 2 \mathrm{H})$; ${ }^{19} \mathrm{~F} \mathrm{NMR}\left(\mathrm{CDCl}_{3}\right): \delta-46.4\left(\mathrm{~s}, \mathrm{SCF}_{3}\right) ;{ }^{13} \mathrm{C} \mathrm{NMR}\left(\mathrm{CDCl}_{3}\right): \delta 118.9$, 128.6 (q, $J=314.2 \mathrm{~Hz}, \mathrm{SCF}_{3}$ ), 158.2, 168.0. IR (neat) $\mathrm{cm}^{-1}: 3482$, 2930, 2854, 1445, 984, 955, 755, 700. HRMS: (ESI-TOF): calcd for $\mathrm{C}_{5} \mathrm{H}_{4} \mathrm{~F}_{3} \mathrm{~N}_{2} \mathrm{~S}_{2}$ 212.9768, found: $212.9762(\mathrm{M}+\mathrm{H})^{+}$.

2-((Trifluoromethyl)sulfinothioyl)benzo[ $d]$ thiazole $(7 \mathrm{~g}) \cdot{ }^{50}(0.8$ mmol of $6 \mathrm{~g}, 0.96 \mathrm{mmol}$ of 1, $4.0 \mathrm{mmol}$ of $p$-toluenesulfonic acid hydrate). Bright brown oil (146 mg, 68\%). ${ }^{1} \mathrm{H}$ NMR $\left(\mathrm{CDCl}_{3}\right): \delta$ 7.38-7.43 (m, 1H), 7.47-7.52 (m, 1H), 7.82-7.86 (m, 1H), 7.93$7.97(\mathrm{~m}, 1 \mathrm{H}) ;{ }^{19} \mathrm{~F}$ NMR $\left(\mathrm{CDCl}_{3}\right): \delta-45.9\left(\mathrm{~s}, \mathrm{SCF}_{3}\right) ;{ }^{13} \mathrm{C} \mathrm{NMR}$ $\left(\mathrm{CDCl}_{3}\right): \delta 121.3,122.8,125.6,126.7,128.2\left(\mathrm{q}, J=315.5 \mathrm{~Hz}, \mathrm{SCF}_{3}\right)$, 136.2, 154.1, 166.5. IR (neat) $\mathrm{cm}^{-1}: 3062,1465,1427,1151,1101$, 1006, 751, 724. HRMS: (ESI-TOF): calcd for $\mathrm{C}_{8} \mathrm{H}_{5} \mathrm{~F}_{3} \mathrm{NS}_{3} 267.9536$, found: $267.9532(\mathrm{M}+\mathrm{H})^{+}$.

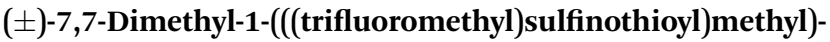
bicyclo[2.2.1] heptan-2-one (9a). (1 mmol of 8a, $1.2 \mathrm{mmol}$ of $\mathbf{1}$, $1.3 \mathrm{mmol}$ of TfOH). Slightly yellow oil (196 mg, 69\%). ${ }^{1} \mathrm{H}$ NMR $\left(\mathrm{CDCl}_{3}\right): \delta 0.92(\mathrm{~s}, 3 \mathrm{H}), 1.05(\mathrm{~s}, 3 \mathrm{H}), 1.38-1.46(\mathrm{~m}, 1 \mathrm{H}), 1.65-1.74$ $(\mathrm{m}, 1 \mathrm{H}), 1.90(\mathrm{~d}, J=18.5 \mathrm{~Hz}, 1 \mathrm{H}), 1.96-2.07(\mathrm{~m}, 2 \mathrm{H}), 2.12(\mathrm{t}, J=$ $4.5 \mathrm{~Hz}, 1 \mathrm{H}$ ), 2.35 (ddd, $J=18.5,4.7,2.4 \mathrm{~Hz}, 1 \mathrm{H}), 2.87$ (d, $J=13.1$ $\mathrm{Hz}, 1 \mathrm{H}), 3.40(\mathrm{~d}, J=13.1 \mathrm{~Hz}, 1 \mathrm{H}) ;{ }^{19} \mathrm{~F} \mathrm{NMR}\left(\mathrm{CDCl}_{3}\right): \delta-47.0(\mathrm{~s}$, $\left.\mathrm{SCF}_{3}\right) ;{ }^{13} \mathrm{C} \mathrm{NMR}\left(\mathrm{CDCl}_{3}\right): \delta 19.8,20.1,26.5,26.7,40.6,42.9,43.6$, 48.0, 61.6, 129.7 (q, $J=313.5 \mathrm{~Hz}, \mathrm{SCF}_{3}$ ), 216.6. IR (neat) $\mathrm{cm}^{-1}$ : 2961, 1740, 1416, 1392, 1374, 1134, 1101, 751. HRMS: (ESI-TOF): calcd for $\mathrm{C}_{11} \mathrm{H}_{16} \mathrm{~F}_{3} \mathrm{OS}_{2}$ 285.0595, found: $285.0600(\mathrm{M}+\mathrm{H})^{+}$.

4-Methyl-7-((trifluoromethyl)sulfinothioyl)-2H-chromen-2-one (9b). ( $0.5 \mathrm{mmol}$ of $\mathbf{8 b}, 0.6 \mathrm{mmol}$ of $\mathbf{1}, 0.6 \mathrm{mmol}$ of $\mathrm{TfOH})$. White solid (113 mg, 77\%), mp 95.2-96.7 ${ }^{\circ} \mathrm{C} .{ }^{1} \mathrm{H} \mathrm{NMR}\left(\mathrm{CDCl}_{3}\right): \delta 2.44$ $(\mathrm{d}, J=1.1 \mathrm{~Hz}, 3 \mathrm{H}), 6.32(\mathrm{~m}, 1 \mathrm{H}), 7.46(\mathrm{dd}, J=8.5,2.0 \mathrm{~Hz}, 1 \mathrm{H})$, $7.56(\mathrm{~d}, J=2.0 \mathrm{~Hz}, 1 \mathrm{H}), 7.60(\mathrm{~d}, J=8.5 \mathrm{~Hz}, 1 \mathrm{H}) ;{ }^{19} \mathrm{~F}$ NMR $\left(\mathrm{CDCl}_{3}\right): \delta-46.1\left(\mathrm{~s}, \mathrm{SCF}_{3}\right) ;{ }^{13} \mathrm{C} \mathrm{NMR}\left(\mathrm{CDCl}_{3}\right): \delta 18.7,115.6,116.4$, 119.9, 123.6, 125.4, 128.7 (q, $J=314.8 \mathrm{~Hz}, \mathrm{SCF}_{3}$ ), 139.2, 151.6, 153.7, 160.0. IR (neat) $\mathrm{cm}^{-1}: 1737,1548,1365,1108,948,877$, 862, 768, 707. Anal. calcd for $\mathrm{C}_{11} \mathrm{H}_{7} \mathrm{~F}_{3} \mathrm{O}_{2} \mathrm{~S}_{2}$ : C, 45.20; H, 2.41. Found: C, 45.12; H, 2.35.

$\mathrm{N}$-(4-Bromophenyl)-2-((trifluoromethyl)sulfinothioyl)acetamide (9c). (2 mmol of $8 \mathrm{c}, 2.4 \mathrm{mmol}$ of $1,2.6 \mathrm{mmol}$ of TfOH). Slightly yellow solid (208 mg, 30\%), mp 87-90 ${ }^{\circ} \mathrm{C} .{ }^{1} \mathrm{H}$ NMR $\left(\mathrm{CDCl}_{3}\right): \delta$ $3.75(\mathrm{~s}, 2 \mathrm{H}), 7.41-7.50(\mathrm{~m}, 4 \mathrm{H}), 7.67(\mathrm{br} \mathrm{s}, 1 \mathrm{H}) ;{ }^{19} \mathrm{~F} \mathrm{NMR}\left(\mathrm{CDCl}_{3}\right)$ : $\delta-46.0\left(\mathrm{~s}, \mathrm{SCF}_{3}\right) ;{ }^{13} \mathrm{C} \mathrm{NMR}\left(\mathrm{CDCl}_{3}\right): \delta 44.3,117.9,121.7,129.1$ (q, $\left.J=314.0 \mathrm{~Hz}, \mathrm{SCF}_{3}\right), 132.1,136.0,164.6$. IR (neat) $\mathrm{cm}^{-1}: 3272$, 1645, 1587, 1532, 1487, 1435, 1349, 1315, 1243, 1126, 1104, 1070, 1011, 971, 936, 822, 684. HRMS: (ESI-TOF) calcd for $\mathrm{C}_{9^{-}}$ $\mathrm{H}_{8} \mathrm{BrF}_{3} \mathrm{NOS}_{2}$ 345.9183, found: $345.9184(\mathrm{M}+\mathrm{H})^{+}$.

1-Phenyl-2-((trifluoromethyl)sulfinothioyl)ethan-1-one (9d). ( $2 \mathrm{mmol}$ of $\mathbf{8 d}, 2.3 \mathrm{mmol}$ of $\mathbf{1}, 10 \mathrm{mmol}$ of $\mathrm{BF}_{3} \cdot \mathrm{Et}_{2} \mathrm{O}$ ). Yellow oil (197 mg, 39\%). ${ }^{1} \mathrm{H}$ NMR $\left(\mathrm{CDCl}_{3}\right): \delta 4.42(\mathrm{~s}, 2 \mathrm{H}), 7.49-7.54(\mathrm{~m}$, 2H), 7.61-7.66 (m, 1H), 7.93-7.97 (m, 2H); ${ }^{19} \mathrm{~F} \mathrm{NMR}\left(\mathrm{CDCl}_{3}\right): \delta$ $-46.5\left(\mathrm{~s}, \mathrm{SCF}_{3}\right) ;{ }^{13} \mathrm{C} \mathrm{NMR}\left(\mathrm{CDCl}_{3}\right): \delta 46.9,128.5,128.9,129.4(\mathrm{q}, J$ $=313.8 \mathrm{~Hz}, \mathrm{SCF}_{3}$ ), 134.1, 135.0, 192.9. IR (neat) $\mathrm{cm}^{-1}: 1677$, 1597, 1581, 1449, 1394, 1321, 1276, 1196, 1135, 1097, 997, 750, 
686, 636. HRMS: (ESI-TOF) calcd for $\mathrm{C}_{9} \mathrm{H}_{8} \mathrm{~F}_{3} \mathrm{OS}_{2}$ 252.9969, found: $252.9970(\mathrm{M}+\mathrm{H})^{+}$.

Phenyl((trifluoromethyl)sulfinothioyl)methanone (9e). (2 mmol of $8 \mathrm{e}, 2.6 \mathrm{mmol}$ of $1,2.6 \mathrm{mmol}$ of $\mathrm{TfOH})$. Slightly yellow oil (176 $\mathrm{mg}, 37 \%) .{ }^{1} \mathrm{H}$ NMR $\left(\mathrm{CDCl}_{3}\right): \delta 7.50-7.58(\mathrm{~m}, 2 \mathrm{H}), 7.65-7.72(\mathrm{~m}, 1 \mathrm{H})$, 7.79-8.05 (m, 2H); ${ }^{19} \mathrm{~F} \mathrm{NMR}\left(\mathrm{CDCl}_{3}\right): \delta-45.9\left(\mathrm{~s}, \mathrm{SCF}_{3}\right) ;{ }^{13} \mathrm{C} \mathrm{NMR}$ $\left(\mathrm{CDCl}_{3}\right): \delta 128.2,128.3$ (q, $\left.J=313.6 \mathrm{~Hz}, \mathrm{SCF}_{3}\right), 129.2,134.6,134.9$, 184.5. IR (neat) $\mathrm{cm}^{-1}: 1760,1708,1597,1581,1449,1201,1145$, 1096, 876, 770, 754, 684, 674, 643, 615. HRMS: (ESI-TOF) calcd for $\mathrm{C}_{8} \mathrm{H}_{6} \mathrm{~F}_{3} \mathrm{OS}_{2} 238.9812$, found: $238.9818(\mathrm{M}+\mathrm{H})^{+}$.

Ethyl acetyl((trifluoromethyl)sulfinothioyl)-D-alaninate (9f). ( $1 \mathrm{mmol}$ of $8 \mathrm{f}, 1.2 \mathrm{mmol}$ of $1,1.2 \mathrm{mmol}$ of MSA). White solid (169 mg, 58\%), mp 41.8-44.7 ${ }^{\circ} \mathrm{C} .{ }^{1} \mathrm{H} \mathrm{NMR}\left(\mathrm{CDCl}_{3}\right): \delta 1.30(\mathrm{t}, J=$ $4.2 \mathrm{~Hz}, 3 \mathrm{H}), 2.05(\mathrm{~s}, 3 \mathrm{H}), 3.32(\mathrm{dd}, J=14.1,5.0 \mathrm{~Hz}, 1 \mathrm{H}), 3.46$ (dd, $J=14.1,5.0 \mathrm{~Hz}, 1 \mathrm{H}), 4.24$ (q, $J=7.2 \mathrm{~Hz}, 2 \mathrm{H}), 4.85-4.90(\mathrm{~m}, 1 \mathrm{H})$, $6.38(\mathrm{~d}, J=6.5 \mathrm{~Hz}, 1 \mathrm{H}) ;{ }^{19} \mathrm{~F} \mathrm{NMR}\left(\mathrm{CDCl}_{3}\right): \delta-46.9\left(\mathrm{~s}, \mathrm{SCF}_{3}\right) ;{ }^{13} \mathrm{C}$ $\mathrm{NMR}\left(\mathrm{CDCl}_{3}\right): \delta 14.0,23.0,41.8,51.6,62.3,129.2$ (q, $J=313.5$ $\mathrm{Hz}, \mathrm{SCF}_{3}$ ), 169.9, 169.9. IR (neat) $\mathrm{cm}^{-1}: 3337,1735,1647,1521$, 1376, 1316, 1189, 1152, 1126, 1103, 1034, 862, 752. $[\alpha]_{\mathrm{D}}^{20}=+37.7$ ( $c=0.26$ in $\mathrm{CH}_{2} \mathrm{Cl}_{2}$ ). HRMS: (ESI-TOF) calcd for $\mathrm{C}_{8} \mathrm{H}_{13} \mathrm{~F}_{3} \mathrm{NO}_{3} \mathrm{~S}_{2}$ 292.0283, found $292.0279(\mathrm{M}+\mathrm{H})^{+}$.

$(2 R, 3 R, 4 S, 5 R, 6 S)$-2-(acetoxymethyl)-6-((trifluoromethyl)sulfinothioyl)tetrahydro-2H-pyran-3,4,5-triyl triacetate (9g). (0.5 $\mathrm{mmol}$ of $8 \mathrm{~g}, 0.6 \mathrm{mmol}$ of $1,0.6 \mathrm{mmol}$ of $\mathrm{TfOH})$. White solid (160 $\mathrm{mg}, 69 \%), \mathrm{mp}$ 113.9-116.2 ${ }^{\circ} \mathrm{C} .{ }^{1} \mathrm{H}$ NMR $\left(\mathrm{CDCl}_{3}\right): \delta 2.02(\mathrm{~s}, 3 \mathrm{H})$, $2.04(\mathrm{~s}, 3 \mathrm{H}), 2.07(\mathrm{~s}, 3 \mathrm{H}), 2.09(\mathrm{~s}, 3 \mathrm{H}), 3.75-3.79(\mathrm{~m}, 1 \mathrm{H}), 4.16$ (dd, $J=12.5,2.2 \mathrm{~Hz}, 1 \mathrm{H}), 4.25(\mathrm{dd}, J=12.5,4.7 \mathrm{~Hz}, 1 \mathrm{H}), 4.62$ (d, $J=10.0 \mathrm{~Hz}, 1 \mathrm{H}), 5.11(\mathrm{dt}, J=9.8,2.3 \mathrm{~Hz}, 2 \mathrm{H}), 5.26(\mathrm{t}, J=9.4 \mathrm{~Hz}$, $1 \mathrm{H}) ;{ }^{19} \mathrm{~F} \mathrm{NMR}\left(\mathrm{CDCl}_{3}\right): \delta-45.9\left(\mathrm{~s}, \mathrm{SCF}_{3}\right) ;{ }^{13} \mathrm{C} \mathrm{NMR}\left(\mathrm{CD}_{3} \mathrm{COCD}_{3}\right)$ : $\delta 21.5,21.5,21.5,63.7,69.8,71.3,74.8,77.6,87.9,130.5(\mathrm{q}, J=$ $\left.313.0 \mathrm{~Hz}, \mathrm{SCF}_{3}\right), 170.9,171.0,171.2,171.6$. IR (neat) $\mathrm{cm}^{-1}: 1742$, $1366,1221,1142,1102,1060,1031,913 .[\alpha]_{\mathrm{D}}^{20}=-100.8(c=0.25$ in $\mathrm{CH}_{2} \mathrm{Cl}_{2}$ ). Anal. calcd for $\mathrm{C}_{15} \mathrm{H}_{19} \mathrm{~F}_{3} \mathrm{O}_{9} \mathrm{~S}_{2}$ : C, 38.79; $\mathrm{H}, 4.12$. Found: C, 39.18; H, 3.80 .

$S$-(Trifluoromethyl) benzenesulfonothioate (11a).$^{47}(1 \mathrm{mmol}$ of 10a, $1.2 \mathrm{mmol}$ of $1,5 \mathrm{mmol}$ of $p$-toluenesulfonic acid monohydrate). Yellow oil $(204 \mathrm{mg}, 84 \%) .{ }^{1} \mathrm{H}$ NMR $\left(\mathrm{CDCl}_{3}\right): \delta 7.59-$ $7.66(\mathrm{~m}, 2 \mathrm{H}), 7.71-7.77(\mathrm{~m}, 1 \mathrm{H}), 7.99-8.04(\mathrm{~m}, 2 \mathrm{H}) ;{ }^{19} \mathrm{~F}$ NMR $\left(\mathrm{CDCl}_{3}\right): \delta-38.9\left(\mathrm{~s}, \mathrm{SCF}_{3}\right) ;{ }^{13} \mathrm{C} \mathrm{NMR}\left(\mathrm{CDCl}_{3}\right): \delta 127.2(\mathrm{q}, J=313.1$ $\mathrm{Hz}, \mathrm{SCF}_{3}$ ), 127.6, 129.6, 135.1, 144.6; IR (neat) $\mathrm{cm}^{-1}: 1449,1359$, 1153, 1095, 1069, 760, 752, 714, 680. Anal. calcd for $\mathrm{C}_{7} \mathrm{H}_{5} \mathrm{~F}_{3} \mathrm{O}_{2} \mathrm{~S}_{2}$ : C, 34.71; H, 2.08. Found: C, 34.64; H, 2.09.

$S$-(Trifluoromethyl) 4-methylbenzenesulfonothioate (11b) ${ }^{59}$ ( $1 \mathrm{mmol}$ of 10b, $1.2 \mathrm{mmol}$ of $1,5 \mathrm{mmol}$ of $p$-toluenesulfonic acid monohydrate). Yellow oil (221 mg, 86\%). ${ }^{1} \mathrm{H}$ NMR $\left(\mathrm{CDCl}_{3}\right): \delta$ $2.49(\mathrm{~s}, 3 \mathrm{H}), 7.37-7.44(\mathrm{~m}, 2 \mathrm{H}), 7.85-7.92(\mathrm{~m}, 2 \mathrm{H}) ;{ }^{19} \mathrm{~F}$ NMR $\left(\mathrm{CDCl}_{3}\right): \delta-39.0\left(\mathrm{~s}, \mathrm{SCF}_{3}\right) ;{ }^{13} \mathrm{C} \mathrm{NMR}\left(\mathrm{CDCl}_{3}\right): \delta 21.8,127.3(\mathrm{q}, J=$ $\left.312.9 \mathrm{~Hz}, \mathrm{SCF}_{3}\right), 127.7,130.2,141.8,146.7$. IR (neat) $\mathrm{cm}^{-1}: 1593$, 1357, 1152, 1097, 1071, 812, 760, 700, 650. Anal. calcd for $\mathrm{C}_{8} \mathrm{H}_{7} \mathrm{~F}_{3} \mathrm{O}_{2} \mathrm{~S}_{2}$ : C, 37.49; H, 2.75. Found: C, 37.31; H, 2.65.

(Phenyl(trifluoromethyl)- $\lambda^{4}$-selanylidene)sulfane (13). (1 mmol of 12, $1.2 \mathrm{mmol}$ of 1, $1.2 \mathrm{mmol}$ of TfOH). Yellow oil (70 $\mathrm{mg}, 54 \%) .{ }^{1} \mathrm{H}$ NMR $\left(\mathrm{CDCl}_{3}\right): \delta 7.34-7.40(\mathrm{~m}, 3 \mathrm{H}), 7.67-7.72(\mathrm{~m}$, $2 \mathrm{H}) ;{ }^{19} \mathrm{~F} \mathrm{NMR}\left(\mathrm{CDCl}_{3}\right): \delta-43.3\left(\mathrm{~s}, \mathrm{SCF}_{3}\right) ;{ }^{13} \mathrm{C} \mathrm{NMR}\left(\mathrm{CDCl}_{3}\right): \delta$ 128.7 (q, $\left.J=311.4 \mathrm{~Hz}, \mathrm{SCF}_{3}\right), 129.4,129.5,130.5,132.7$. IR (neat) $\mathrm{cm}^{-1}$ : 1135, 1090, 733, 685. HRMS: (APCI + PI) calcd for $\mathrm{C}_{7} \mathrm{H}_{5} \mathrm{~F}_{3} \mathrm{SSe} 257.9229$, found 257.9224 .
1-Methyl-2-nitro-4-((trifluoromethyl)sulfinothioyl)benzene (14). Yellow solid (114 mg, 71\%), mp 51.0-52.0 ${ }^{\circ} \mathrm{C} .{ }^{1} \mathrm{H}$ NMR $\left(\mathrm{CDCl}_{3}\right): \delta$ 2.47 (s, 3H), $7.55(\mathrm{dd}, J=8.4,1.1 \mathrm{~Hz}, 1 \mathrm{H}), 8.03(\mathrm{~d}, J=8.4 \mathrm{~Hz}$, $1 \mathrm{H}), 8.11(\mathrm{~d}, J=1.1 \mathrm{~Hz}, 1 \mathrm{H}) ;{ }^{19} \mathrm{~F} \mathrm{NMR}\left(\mathrm{CDCl}_{3}\right): \delta-45.0\left(\mathrm{~s}, \mathrm{SCF}_{3}\right)$; ${ }^{13} \mathrm{C} \mathrm{NMR}\left(\mathrm{CDCl}_{3}\right): \delta 20.5,126.3,127.3,128.7$ (q, $J=314.6 \mathrm{~Hz}$, $\mathrm{SCF}_{3}$ ), 130.9, 135.6, 138.4, 145.4. IR (neat) $\mathrm{cm}^{-1}: 2923,1514$, 1463, 1329, 1294, 1143, 1091, 829, 802, 750. HRMS: (APCI + PI) calcd for $\mathrm{C}_{8} \mathrm{H}_{6} \mathrm{~F}_{3} \mathrm{NO}_{2} \mathrm{~S}_{2}$ 268.9786, found 268.9785 .

\section{Acknowledgements}

J. Robin and B. Alič for technical support, Prof. K. Francesconi and Dr K. B. Jensen at the Karl-Franzens-University in Graz, Dr D. Urankar and Prof. J. Košmrlj for HRMS, Mrs T. Stipanovič and Prof. B. Stanovnik for elemental combustion analyses, and the Ministry of Higher Education, Science and Technology (P1-0134) for financial support are gratefully acknowledged.

\section{References}

1 (a) P. Kirsch, Modern Fluoroorganic Chemistry: Synthesis, Reactivity, Applications, Wiley-VCH, Weinheim, 2006; (b) Handbook of Fluorous Chemistry, ed. J. A. Gladysz, D. P. Curran and I. T. Horváth, Wiley-VCH, Weinheim, 2004; (c) W. K. Hagmann, J. Med. Chem., 2008, 51, 4359-4369; (d) T. Liang, C. N. Neumann and T. Ritter, Angew. Chem., Int. Ed., 2013, 52, 8214-8264; (e) K. Müller, C. Faeh and F. Diederich, Science, 2007, 317, 1881-1886; (f) D. O'Hagan, J. Fluorine Chem., 2010, 131, 1071-1081; $(g)$ R. Berger, G. Resnati, P. Metrangolo, E. Weber and J. Hulliger, Chem. Soc. Rev., 2011, 40, 3496-3508; (h) M. G. Campbell and T. Ritter, Chem. Rev., 2015, 115, 612-633.

2 (a) D. O'Hagan, Chem. Soc. Rev., 2008, 37, 308-319; (b) L. Hunter, Beilstein J. Org. Chem., 2010, 6, 38; (c) G. A. Patani and E. J. LaVoie, Chem. Rev., 1996, 96, 31473176.

3 (a) E. A. Meyer, R. K. Castellano and F. Diederich, Angew. Chem., Int. Ed., 2003, 42, 1210-1250; (b) C. Dalvit and A. Vulpetti, ChemMedChem, 2012, 7, 262-272.

4 (a) H.-J. Schneider, Chem. Sci., 2012, 3, 1381-1394; (b) D. Chopra and T. N. Guru Row, CrystEngComm, 2011, 13, 2175-2186; (c) K. Reichenbächer, H. I. Süss and J. Hulliger, Chem. Soc. Rev., 2005, 34, 22-30.

5 (a) Z. Jin, G. B. Hammond and B. Xu, Aldrichimica Acta, 2012, 45, 67-83; (b) N. Shibata, A. Matsnev and D. Cahard, Beilstein J. Org. Chem., 2010, 6, 65; (c) A. Studer, Angew. Chem., Int. Ed., 2012, 51, 8950-8958; (d) O. A. Tomashenko and V. V. Grushin, Chem. Rev., 2011, 111, 4475-4521; (e) T. Furuya, A. S. Kamlet and T. Ritter, Nature, 2011, 473, 470-477; $(f)$ T. Besset, C. Schneider and D. Cahard, Angew. Chem., Int. Ed., 2012, 51, 5048-5050; (g) X.-F. Wu, H. Neumann and M. Beller, Chem.-Asian J., 2012, 7, 17441754.

6 (a) S. Purser, P. R. Moore, S. Swallow and V. Gouverneur, Chem. Soc. Rev., 2008, 37, 320-330; (b) K. L. Kirk, J. Fluorine Chem., 2006, 127, 1013-1029; (c) J. Xu, X. Liu and Y. Fu, Tetrahedron Lett., 2014, 55, 585-594; (d) W. Zhu, J. Wang, 
S. Wang, Z. Gu, J. L. Aceña, K. Izawa, H. Liu and V. A. Soloshonok, J. Fluorine Chem., 2014, 167, 37-54; (e) E. Merino and C. Nevado, Chem. Soc. Rev., 2014, 43, 65986608; (f) J.-A. Ma and D. Cahard, Chem. Rev., 2008, 108, PR1-PR43; $(g)$ H. Egami and M. Sodeoka, Angew. Chem., Int. Ed., 2014, 53, 8294-8308.

7 L. M. Yagupolskii, N. V. Kondratenko and G. N. Timofeeva, J. Org. Chem. USSR, 1984, 20, 103-106.

8 (a) T. Umemoto and J. Ishihara, J. Am. Chem. Soc., 1993, 115, 2156-2164; (b) J.-J. Yang, R. L. Kirchmeier and J. M. Shreeve, J. Org. Chem., 1998, 63, 2656-2660; (c) S. Noritake, N. Shibata, S. Nakamura, T. Toru and M. Shiro, Eur. J. Org. Chem., 2008, 3465-3468; (d) A. Matsnev, S. Noritake, Y. Nomura, E. Tokunaga, S. Nakamura and N. Shibata, Angew. Chem., Int. Ed., 2010, 49, 572-576; (e) P. Eisenberger, S. Gischig and A. Togni, Chem.-Eur. J., 2006, 12, 2579-2586; $(f)$ A. T. Parsons and S. L. Buchwald, Angew. Chem., Int. Ed., 2011, 50, 9120-9123; (g) T. Liu, X. Shao, Y. Wu and Q. Shen, Angew. Chem., Int. Ed., 2012, 51, 540-543; (h) R. Shimizu, H. Egami, Y. Hamashima and M. Sodeoka, Angew. Chem., Int. Ed., 2012, 51, 4577-4580; (i) Y. Li and A. Studer, Angew. Chem., Int. Ed., 2012, 51, 8221-8224.

9 See, for example: (a) C. Zhang, Org. Biomol. Chem., 2014, 12, 6580-6589; (b) L. Chu and F.-L. Qing, Acc. Chem. Res., 2014, 47, 1513-1522; (c) T. Besset, T. Poisson and X. Pannecoucke, Chem.-Eur. J., 2014, 20, 16830-16845; (d) S. Barata-Vallejo, B. Lantaño and A. Postigo, Chem.-Eur. J., 2014, 20, 16806-16829; (e) W. Kong, M. Casimiro, N. Fuentes, E. Merino and C. Nevado, Angew. Chem., Int. Ed., 2013, 52, 13086-13090; (f) J. Charpentier, N. Früh and A. Togni, Chem. Rev., 2015, 115, 650-682.

10 See, for example: (a) J. Xu, B. Xiao, C.-Q. Xie, D.-F. Luo, L. Liu and Y. Fu, Angew. Chem., Int. Ed., 2012, 51, 12551-12554; (b) X. Mu, T. Wu, H.-y. Wang, Y.-l. Guo and G. Liu, J. Am. Chem. Soc., 2012, 134, 878-881; (c) B. A. Khan, A. E. Buba and L. J. Gooßen, Chem.-Eur. J., 2012, 18, 1577-1581; (d) A. Hafner and S. Bräse, Angew. Chem., Int. Ed., 2012, 51, 3713-3715; (e) L. Chu and F.-L. Qing, J. Am. Chem. Soc., 2010, 132, 7262-7263; (f) M. Shang, S.-Z. Sun, H.-L. Wang, B. N. Laforteza, H.-X. Dai and J.-Q. Yu, Angew. Chem., Int. Ed., 2014, 53, 10439-10442; (g) P. V. Pham, D. A. Nagib and D. W. C. MacMillan, Angew. Chem., Int. Ed., 2011, 50, 61196122; (h) X. Liu, C. Xu, M. Wang and Q. Liu, Chem. Rev., 2015, 115, 683-730.

11 See, for example: (a) G. Shi, C. Shao, S. Pan, J. Yu and Y. Zhang, Org. Lett., 2015, 17, 38-41; (b) Y. Ye and M. S. Sanford, J. Am. Chem. Soc., 2012, 134, 9034-9037; (c) X.-Y. Jiang and F.-L. Qing, Angew. Chem., Int. Ed., 2013, 52, 14177-14180; (d) Q. Lu, C. Liu, Z. Huang, Y. Ma, J. Zhang and A. Lei, Chem. Commun., 2014, 50, 14101-14104; (e) L. Zhang, Z. Li and Z.-Q. Liu, Org. Lett., 2014, 16, 36883691; (f) N. Iqbal, J. Jung, S. Park and E. J. Cho, Angew. Chem., Int. Ed., 2014, 53, 539-542; (g) X. Wu, L. Chu and F.-L. Qing, Angew. Chem., Int. Ed., 2013, 52, 2198-2202; (h) S. Mizuta, S. Verhoog, K. M. Engle, T. Khotavivattana, M. O'Duill, K. Wheelhouse, G. Rassias, M. Médebielle and
V. Gouverneur, J. Am. Chem. Soc., 2013, 135, 2505-2508; (i)

C. Zhang, Adv. Synth. Catal., 2014, 356, 2895-2906.

12 See, for example: (a) R. J. Lundgren and M. Stradiotto, Angew. Chem., Int. Ed., 2010, 49, 9322-9324; (b) N. D. Ball, J. W. Kampf and M. S. Sanford, J. Am. Chem. Soc., 2010, 132, 2878-2879; (c) T. S. N. Zhao and K. J. Szabó, Org. Lett., 2012, 14, 3966-3969; (d) O. A. Tomashenko, E. C. Escudero-Adán, M. M. Belmonte and V. V. Grushin, Angew. Chem., Int. Ed., 2011, 50, 7655-7659; (e) G. G. Dubinina, H. Furutachi and D. A. Vicic, J. Am. Chem. Soc., 2008, 130, 8600-8601; (f) N. D. Ball, J. B. Gary, Y. Ye and M. S. Sanford, J. Am. Chem. Soc., 2011, 133, 7577-7584; (g) E. J. Cho, T. D. Senecal, T. Kinzel, Y. Zhang, D. A. Watson and S. L. Buchwald, Science, 2010, 328, 16791681; (h) N. D. Litvinas, P. S. Fier and J. F. Hartwig, Angew. Chem., Int. Ed., 2012, 51, 536-539; (i) H. Morimoto, T. Tsubogo, N. D. Litvinas and J. F. Hartwig, Angew. Chem., Int. Ed., 2011, 50, 3793-3798; (j) L. Zhu, S. Liu, J. T. Douglas and R. A. Altman, Chem.-Eur. J., 2013, 19, 12800-12805; ( $k$ ) P. Chen and G. Liu, Synthesis, 2013, 45, 2919-2939; (l) Y. Ye and M. S. Sanford, Synlett, 2012, 23, 2000-2013; (m) M. Hu, C. Ni and J. Hu, J. Am. Chem. Soc., 2012, 134, 15257-15260; (n) T. Liu and Q. Shen, Eur. J. Org. Chem., 2012, 6679-6687; (o) J. M. Larsson, S. R. Pathipati and K. J. Szabó, J. Org. Chem., 2013, 78, 7330-7336.

13 G. Landelle, A. Panossian and F. R. Leroux, Curr. Top. Med. Chem., 2014, 14, 941-951.

14 K. Fauster, C. Kreutz and R. Micura, Angew. Chem., Int. Ed., 2012, 51, 13080-13084.

15 (a) G. Teverovskiy, D. S. Surry and S. L. Buchwald, Angew. Chem., Int. Ed., 2011, 50, 7312-7314; (b) K. Zhang, J.-B. Liu and F.-L. Qing, Chem. Commun., 2014, 50, 14157-14160; (c) L. M. Yagupolskii, N. V. Kondratenko and V. P. Sambur, Synthesis, 1975, 721-723; (d) M. Hu, J. Rong, W. Miao, C. Ni, Y. Han and J. Hu, Org. Lett., 2014, 16, 2030-2033; (e) S.-G. Li and S. Z. Zard, Org. Lett., 2013, 15, 5898-5901; (f) W. A. Sheppard, J. Org. Chem., 1964, 29, 895-898; $(g)$ D. J. Adams, A. Goddard, J. H. Clark and D. J. Macquarrie, Chem. Commun., 2000, 987-988; (h) C.-P. Zhang and D. A. Vicic, J. Am. Chem. Soc., 2012, 134, 183-185; (i) C.-P. Zhang and D. A. Vicic, Chem.-Asian J., 2012, 7, 17561758.

16 V. N. Boiko, Beilstein J. Org. Chem., 2010, 6, 880-921.

17 (a) K. Yamaguchi, K. Sakagami, Y. Miyamoto, X. Jin and N. Mizuno, Org. Biomol. Chem., 2014, 12, 9200-9206; (b) C. Chen, Y. Xie, L. Chu, R.-W. Wang, X. Zhang and F.-L. Qing, Angew. Chem., Int. Ed., 2012, 51, 2492-2495; (c) C. Pooput, M. Medebielle and W. R. Dolbier Jr, Org. Lett., 2004, 6, 301-303; (d) N. Santschi and A. Togni, J. Org. Chem., 2011, 76, 4189-4193; (e) I. Kieltsch, P. Eisenberger and A. Togni, Angew. Chem., Int. Ed., 2007, 46, 754-757; (f) S. Capone, I. Kieltsch, O. Flögel, G. Lelais, A. Togni and D. Seebach, Helv. Chim. Acta, 2008, 91, 2035-2056; $(g)$ S. Large, N. Roques and B. R. Langlois, J. Org. Chem., 2000, 65, 8848-8856; $(h)$ T. Billard, S. Large and B. R. Langlois, Tetrahedron Lett., 1997, 38, 65-68; (i) G. Blond, T. Billard and B. R. Langlois, Tetrahedron Lett., 2001, 42, 2473-2475; 
(j) L. Zhai, Y. Li, J. Yin, K. Jin, R. Zhang, X. Fu and C. Duan, Tetrahedron, 2013, 69, 10262-10266; (k) Y. Huang, X. He, X. Lin, M. Rong and Z. Weng, Org. Lett., 2014, 16, 32843287; (l) V. N. Movchun, A. A. Kolomeitsev and Y. L. Yagupolskii, J. Fluorine Chem., 1995, 70, 255-257; (m) W. Zhong and X. Liu, Tetrahedron Lett., 2014, 55, 49094911; (n) G. Danoun, B. Bayarmagnai, M. F. Gruenberg and J. L. Goossen, Chem. Sci., 2014, 5, 1312-1316; (o) N. J. W. Straathof, B. J. P. Tegelbeckers, V. Hessel, X. Wang and T. Noël, Chem. Sci., 2014, 5, 4768-4773; ( $p)$ B. Bayarmagnai, C. Matheis, E. Risto and L. J. Goossen, Adv. Synth. Catal., 2014, 356, 2343-2348.

18 (a) M. Rueping, N. Tolstoluzhsky and P. Nikolaienko, Chem.Eur. J., 2013, 19, 14043-14046; (b) Z. Weng, W. He, C. Chen, R. Lee, D. Tan, Z. Lai, D. Kong, Y. Yuan and K.-W. Huang, Angew. Chem., Int. Ed., 2013, 52, 1548-1552; (c) J. H. Clark, C. W. Jones, A. P. Kybett, M. A. McClinton, J. M. Miller, D. Bishop and R. J. Blade, J. Fluorine Chem., 1990, 48, 249253; (d) D. J. Adams and J. H. Clark, J. Org. Chem., 2000, 65, 1456-1460.

19 L. D. Tran, I. Popov and O. Daugulis, J. Am. Chem. Soc., 2012, 134, 18237-18240.

20 S. Munavalli, D. K. Rohrbaugh, D. I. Rossman and H. D. Durst, J. Fluorine Chem., 1999, 98, 3-9.

21 (a) A. Tlili and T. Billard, Angew. Chem., Int. Ed., 2013, 52, 6818-6819; (b) F. Toulgoat, S. Alazet and T. Billard, Eur. J. Org. Chem., 2014, 2415-2428; (c) X.-H. Xu, K. Matsuzaki and N. Shibata, Chem. Rev., 2015, 115, 731-764; (d) C. Shen, P. Zhang, Q. Sun, S. Bai, T. S. A. Hor and X. Liu, Chem. Soc. Rev., 2015, 44, 291-314; (e) C. Chen, L. Chu and F.-L. Qing, J. Am. Chem. Soc., 2012, 134, 12454-12457; (f) Q. Lefebvre, E. Fava, P. Nikolaienko and M. Rueping, Chem. Commun., 2014, 50, 6617-6619; (g) W. Yin, Z. Wang and Y. Huang, Adv. Synth. Catal., 2014, 356, 2998-3006; (h) P. Nikolaienko, R. Pluta and M. Rueping, Chem.-Eur. J., 2014, 20, 9867-9870; (i) C. Chen, X.-H. Xu, B. Yang and F.-L. Qing, Org. Lett., 2014, 16, 3372-3375; (j) P. Zhu, X. He, X. Chen, Y. You, Y. Yuan and Z. Weng, Tetrahedron, 2014, 70, 672-677; (k) D. Kong, Z. Jiang, S. Xin, Z. Bai, Y. Yuan and Z. Weng, Tetrahedron, 2013, 69, 6046-6050; (l) Z. Wang, Q. Tu and Z. Weng, J. Organomet. Chem., 2014, 751, 830-834; $(m)$ Q. Xiao, J. Sheng, Q. Ding and J. Wu, Eur. J. Org. Chem., 2014, 217-221; (n) F. Yin and X.-S. Wang, Org. Lett., 2014, 16, 1128-1131; (o) X. Wang, Y. Zhou, G. Ji, G. Wu, M. Li, Y. Zhang and J. Wang, Eur. J. Org. Chem., 2014, 3093-3096; ( $p$ ) G. Landelle, A. Panossian, S. Pazenok, J.-P. Vors and F. R. Leroux, Beilstein J. Org. Chem., 2013, 9, 2476-2536; (q) J.-B. Liu, X.-H. Xu, Z.-H. Chen and F.-L. Qing, Angew. Chem., Int. Ed., 2015, 54, 897-900; (r) X. Dai and D. Cahard, Synlett, 2015, 16, 40-44.

22 A. Ferry, T. Billard, B. R. Langlois and E. Bacqué, J. Org. Chem., 2008, 73, 9362-9365.

23 A. Ferry, T. Billard, B. R. Langlois and E. Bacqué, Angew. Chem., Int. Ed., 2009, 48, 8551-8555.

24 A. Ferry, T. Billard, E. Bacque and B. R. Langlois, J. Fluorine Chem., 2012, 134, 160-163.
25 F. Baert, J. Colomb and T. Billard, Angew. Chem., Int. Ed., 2012, 51, 10382-10385.

26 Y. Yang, X. Jiang and F.-L. Qing, J. Org. Chem., 2012, 77, 7538-7547.

27 S. Alazet, K. Ollivier and T. Billard, Beilstein J. Org. Chem., 2013, 9, 2354-2357.

28 J. Liu, L. Chu and F.-L. Qing, Org. Lett., 2013, 15, 894-897.

29 M. Jereb and K. Gosak, Org. Biomol. Chem., 2015, 13, 31033115.

30 J. Sheng, S. Li and J. Wu, Chem. Commun., 2014, 50, 578-580.

31 J. Sheng, C. Fan and J. Wu, Chem. Commun., 2014, 50, 54945496.

32 Y. Li, G. Li and Q. Ding, Eur. J. Org. Chem., 2014, 5017-5022. 33 Q. Xiao, J. Sheng, Z. Chen and J. Wu, Chem. Commun., 2013, 49, 8647-8649.

34 Q. Xiao, H. Zhu, G. Li and Z. Chen, Adv. Synth. Catal., 2014, 356, 3809-3815.

35 (a) Y.-D. Yang, A. Azuma, E. Tokunaga, M. Yamasaki, M. Shiro and M. Shibata, J. Am. Chem. Soc., 2013, 135, 8782-8785; (b) S. Arimori, M. Takada and N. Shibata, Org. Lett., 2015, 17, 1063-1065; (c) Z. Huang, Y.-D. Yang, E. Tokunaga and N. Shibata, Org. Lett., 2015, 17, 1094-1097.

36 C. Xu and Q. Shen, Org. Lett., 2014, 16, 2046-2049.

37 S.-Q. Zhu, X.-H. Xu and F.-L. Qing, Eur. J. Org. Chem., 2014, 4453-4456.

38 K. Kang, C. Xu and Q. Shen, Org. Chem. Front., 2014, 1, 294297.

39 R. Pluta, P. Nikolaienko and M. Rueping, Angew. Chem., Int. Ed., 2014, 53, 1650-1653.

40 R. Pluta and M. Rueping, Chem.-Eur. J., 2014, 20, 1731517318.

41 T. Bootwicha, X. Liu, R. Pluta, I. Atodiresei and M. Rueping, Angew. Chem., Int. Ed., 2013, 52, 12856-12859.

42 M. Rueping, X. Liu, T. Bootwicha, R. Pluta and C. Merkens, Chem. Commun., 2014, 50, 2508-2511.

43 X. Shao, X. Wang, T. Yang, L. Lu and Q. Shen, Angew. Chem., Int. Ed., 2013, 52, 3457-3460.

44 E. V. Vinogradova, P. Müller and S. L. Buchwald, Angew. Chem., Int. Ed., 2014, 53, 3125-3128.

45 X. Shao, T. Liu, L. Lu and Q. Shen, Org. Lett., 2014, 16, 47384741.

46 B. Ma, X. Shao and Q. Shen, J. Fluorine Chem., 2015, 171, 7377.

47 X. Shao, C. Xu, L. Lu and Q. Shen, J. Org. Chem., 2015, 80, 3012-3021.

48 F. Hu, X. Shao, D. Zhu, L. Lu and Q. Shen, Angew. Chem., Int. Ed., 2014, 53, 6105-6109.

49 H. He and X. Zhu, Org. Lett., 2014, 16, 3102-3105.

50 (a) X. Wang, T. Yang, X. Cheng and Q. Shen, Angew. Chem., Int. Ed., 2013, 52, 12860-12864; (b) Q.-H. Deng, C. Rettenmeier, H. Wadepohl and L. H. Gade, Chem.-Eur. J., 2014, 20, 93-97.

51 C. Xu, B. Ma and Q. Shen, Angew. Chem., Int. Ed., 2014, 53, 9316-9320.

52 Q. Wang, Z. Qi, F. Xie and X. Li, Adv. Synth. Catal., 2014, 357, 355-360. 
53 M. Maeno, N. Shibata and D. Cahard, Org. Lett., 2015, 17, 1990-1993.

54 X.-L. Zhu, J.-H. Xu, D.-J. Cheng, L.-J. Zhao, X.-Y. Liu and B. Tan, Org. Lett., 2014, 16, 2192-2195.

55 H. Xiang and C. Yang, Org. Lett., 2014, 16, 5686-5689.

56 S. Alazet, L. Zimmer and T. Billard, Chem.-Eur. J., 2014, 20, 8589-8593.

57 (a) S. Alazet and T. Billard, Synlett, 2015, 26, 76-78; (b) S. Alazet, L. Zimmer and T. Billard, J. Fluorine Chem., 2015, 171, 78-81.

58 S. S. Block and J. P. Weidner, Nature, 1967, 214, 478-479.

59 J. P. Weidner and S. S. Block, J. Med. Chem., 1967, 10, 11671170.

$60 \mathrm{~S}$. Andreades, J. F. Harris Jr and W. A. Sheppard, J. Org. Chem., 1964, 29, 898-900.

61 D. M. Ceacareanu, M. R. C. Gerstenberger and A. Haas, Chem. Ber., 1983, 116, 3325-3331.

62 S. Munavalli, D. I. Rossman, D. K. Rohrbaugh, C. P. Ferguson and H. D. Banks, J. Fluorine Chem., 1993, 60, 85-91.

63 T. Billard, N. Roques and B. R. Langlois, J. Org. Chem., 1999, 64, 3813-3820.

64 A. Fischer, W. Grab and P. Schieberle, Eur. Food Res. Technol., 2008, 227, 735-744.

65 (a) J. P. Weidner and S. S. Block, J. Med. Chem., 1972, 15, 564567; (b) T. Billard, B. R. Langlois, S. Large, D. Anker, N. Roidot and P. Roure, J. Org. Chem., 1996, 61, 7545-7550. 66 M. G. Ranasinghe and P. L. Fuchs, J. Am. Chem. Soc., 1989, 111, 779-782.

67 (a) B. J. Lynch, P. L. Fast, M. Harris and D. G. Truhlar, J. Phys. Chem. A, 2000, 104, 4811-4815; (b) Y. Zhao and D. G. Truhlar,
J. Chem. Theory Comput., 2005, 1, 415-432; (c) D. Dolenc and B. Modec, New J. Chem., 2009, 33, 2344-2349.

68 E. D. Glendening, J. K. Badenhoop, A. E. Reed, J. E. Carpenter, J. A. Bohmann, C. M. Morales and F. Weinhold, NBO 5.0, Theoretical Chemistry Institute, University of Wisconsin, Madison, WI, 2001, http:// www.chem.wisc.edu/ nbo5.

69 C. E. Aroyan, A. Dermenci and S. J. Miller, J. Org. Chem., 2010, 75, 5784-5796.

70 S. Pearson, W. Scarano and M. H. Stenzel, Chem. Commun., 2012, 48, 4695-4697.

71 E. Juaristi and J. S. Cruz-Sánchez, J. Org. Chem., 1988, 53, 3334-3338.

72 J. Z. Chandanshive, B. F. Bonini, D. Gentili, M. Fochi, L. Bernardi and M. Comes Franchini, Eur. J. Org. Chem., 2010, 6440-6447.

73 S. Knoppe, N. Kothalawala, V. R. Jupally, A. Dass and T. Bürgi, Chem. Commun., 2012, 48, 4630-4632.

74 S. J. Ratnakar, M. Woods, A. J. M. Lubag, Z. Kovács and A. D. Sherry, J. Am. Chem. Soc., 2008, 130, 6-7.

75 S. Bateja, S. Chandrashekhar, C. S. Bhandari and N. C. Sogani, J. Chin. Chem. Soc., 1979, 26, 173-176.

76 J. J. Garcia, B. E. Mann, H. Adams, N. A. Bailey and P. M. Maitlis, J. Am. Chem. Soc., 1995, 117, 2179-2186.

77 J. I. G. Cadogan, H. S. Hutchinson and H. McNab, J. Chem. Soc., Perkin Trans. 1, 1988, 2875-2879.

78 M. Murár, G. Addová and A. Boháč, Beilstein J. Org. Chem., 2013, 9, 173-179.

79 R. E. Pearson and J. C. Martin, J. Am. Chem. Soc., 1963, 85, 3142-3146.

80 C. K. Ingold and F. R. Shaw, J. Chem. Soc., 1927, 2918-2926. 